
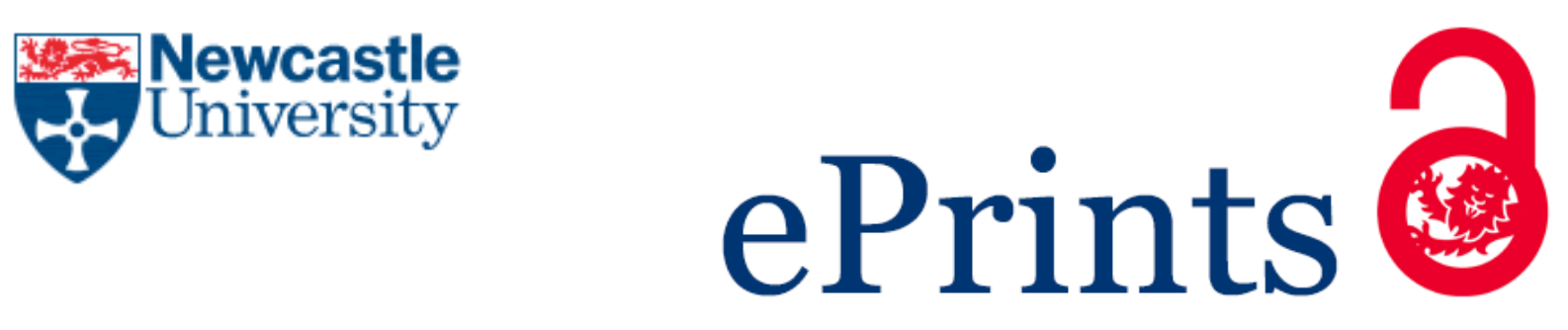

Toet S, Oliver V, Ineson P, McLoughlin S, Helgason T, Peacock S, Stott A, Barnes J, Ashmore M. How does elevated ozone reduce methane emissions from peatlands? Science of the Total Environment 2017, 579, 60-71.

\title{
Copyright:
}

(C) 2016. This manuscript version is made available under the CC-BY-NC-ND 4.0 license

DOI link to article:

http://dx.doi.org/10.1016/i.scitotenv.2016.10.188

Date deposited:

$04 / 01 / 2017$

Embargo release date:

17 November 2017

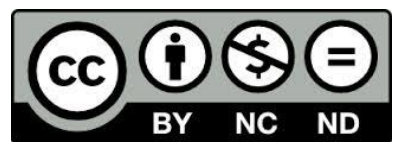

This work is licensed under a

Creative Commons Attribution-NonCommercial-NoDerivatives 4.0 International licence 


\section{How does elevated ozone reduce methane emissions from peatlands?}

Sylvia Toet ${ }^{\mathrm{a}}$, Viktoria Oliver ${ }^{\mathrm{a}, 1}$, Phil Ineson ${ }^{\mathrm{b}}$, Sophie McLoughlin ${ }^{\mathrm{a}}$, Thorunn Helgason ${ }^{\mathrm{b}}$, Simon Peacock ${ }^{\mathrm{c}, 2}$, Andrew W. Stott ${ }^{\mathrm{d}}$, Jeremy Barnes $^{\mathrm{c}} \&$ Mike Ashmore $^{\mathrm{e}}$

${ }^{a}$ Environment Department, University of York, York, YO10 5NG, UK

${ }^{\mathrm{b}}$ Department of Biology, University of York, York, YO10 5DD, UK

${ }^{c}$ School of Biology, Newcastle University, Newcastle upon Tyne, NE1 7RU, UK

${ }^{d}$ Natural Environment Research Council Life Sciences Mass Spectrometry Facility, Centre for Ecology and Hydrology, Lancaster, LA1 4AP, UK

e Stockholm Environment Institute, University of York, York, YO10 5NG, UK

Corresponding author: Sylvia Toet

tel. +441904324018

fax +44 1904432998

e-mail: sylvia.toet@york.ac.uk

1 present address: The School of Biological Sciences, Aberdeen AB24 2TZ, UK

${ }^{2}$ present address: School of Agriculture, Food and Rural Development, Newcastle University, NE1 7RU, UK 


\section{Abstract}

The effects of increased tropospheric ozone $\left(\mathrm{O}_{3}\right)$ pollution levels on methane $\left(\mathrm{CH}_{4}\right)$ emissions from peatlands, and their underlying mechanisms, remain unclear. In this study, we exposed peatland mesocosms from a temperate wet heath dominated by the sedge Schoenus nigricans and Sphagnum papillosum to four $\mathrm{O}_{3}$ treatments in open-top chambers for 2.5 years, to investigate the $\mathrm{O}_{3}$ impacts on $\mathrm{CH}_{4}$ emissions and the processes that underpin these responses. Summer $\mathrm{CH}_{4}$ emissions, were significantly reduced, by $27 \%$ over the experiment, due to

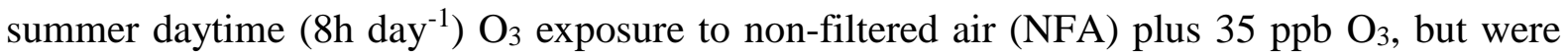
not significantly affected by year-round, $24 \mathrm{~h} \mathrm{day}^{-1}$, exposure to NFA plus $10 \mathrm{ppb}$ or NFA plus $25 \mathrm{ppb} \mathrm{O}_{3}$. There was no evidence that the reduced $\mathrm{CH}_{4}$ emissions in response to elevated summer $\mathrm{O}_{3}$ exposure were caused by reduced plant-derived carbon availability below-ground, because we found no significant effect of high summer $\mathrm{O}_{3}$ exposure on root biomass, pore water dissolved organic carbon concentrations or the contribution of recent photosynthate to $\mathrm{CH}_{4}$ emissions. Our $\mathrm{CH}_{4}$ production potential and $\mathrm{CH}_{4}$ oxidation potential measurements in the different $\mathrm{O}_{3}$ treatments could also not explain the observed $\mathrm{CH}_{4}$ emission responses to $\mathrm{O}_{3}$. However, pore water ammonium concentrations at $20 \mathrm{~cm}$ depth were consistently reduced during the experiment by elevated summer $\mathrm{O}_{3}$ exposure, and strong positive correlations were observed between $\mathrm{CH}_{4}$ emission and pore water ammonium concentration at three peat depths over the 2.5-year study. Our results therefore imply that elevated regional $\mathrm{O}_{3}$ exposures in summer, but not the small increases in northern hemisphere annual mean background $\mathrm{O}_{3}$ concentrations predicted over this century, may lead to reduced $\mathrm{CH}_{4}$ emissions from temperate peatlands as a consequence of reductions in soil inorganic nitrogen affecting methanogenic and/or methanotrophic activity. 
Keywords: $\mathrm{CH}_{4}$; mires; sedge; Sphagnum papillosum; nitrogen; ${ }^{13} \mathrm{C}$.

\section{Introduction}

Tropospheric ozone $\left(\mathrm{O}_{3}\right)$ and methane $\left(\mathrm{CH}_{4}\right)$ are the second and third most important contributors to the human-induced greenhouse effect after carbon dioxide (IPCC, 2013). The concentrations of both gases in the background troposphere increased over the last century and, without strong emission control, are predicted to increase further during the $21^{\text {st }}$ century (Dentener et al., 2006; Royal Society 2008; Wild et al., 2012). Recently, increased attention has been paid to the importance of measures to control atmospheric $\mathrm{O}_{3}$ and $\mathrm{CH}_{4}$ concentrations, because of their relatively short atmospheric lifetimes compared to $\mathrm{CO}_{2}$ (Shindell et al., 2012). There are also important feedbacks between these two gases, since $\mathrm{CH}_{4}$ emissions have contributed significantly to increases in global background $\mathrm{O}_{3}$ concentrations (West \& Fiore, 2005).

Ozone is also the most important gaseous air pollutant globally in terms of effects on ecosystem production and function (Ashmore, 2005) and northern hemisphere background levels of $\mathrm{O}_{3}$ already exceed those at which significant effects on wild plant communities, crop yields and forest productivity can occur (Davison \& Barnes, 1998; Averny et al., 2011; Ainsworth et al., 2012). Global modelling of $\mathrm{O}_{3}$ effects on $\mathrm{CO}_{2}$ uptake and sequestration suggest that these indirect effects may be as important as the direct effects of $\mathrm{O}_{3}$ on radiative forcing (Sitch et al., 2007). However, these simulations do not consider the possibility that $\mathrm{O}_{3}$ may affect $\mathrm{CH}_{4}$ fluxes from managed and unmanaged wetlands. Methane emissions from natural wetlands may have contributed significantly to recent increases in global $\mathrm{CH}_{4}$ levels (Kirschke et al., 2013), while predicted future releases of $\mathrm{CH}_{4}$ from Arctic permafrost 
thawing could be large enough to substantially increase tropospheric $\mathrm{O}_{3}$ levels (Isaksen et al., 2014).

We have previously reported (Toet et al., 2011) that exposure to environmentallyrelevant levels of elevated $\mathrm{O}_{3}$ in the daytime decreased summer $\mathrm{CH}_{4}$ emissions from temperate peatland mesocosms by ca. 25\%. In contrast, Mörsky et al. (2008) reported that open-field exposure of boreal peatland microcosms to a similar increase in $\mathrm{O}_{3}$ concentration in Central Finland only caused a decrease in $\mathrm{CH}_{4}$ emission at the end of the first growing season, which was lost in the three subsequent growing seasons. Recently, Williamson et al. (2016) reported both increases and decreases in $\mathrm{CH}_{4}$ emissions from temperate upland bog mesocosms in response to increasing background $\mathrm{O}_{3}$ exposures in a short-term summer experiment. Studies on rice paddies, all also elevating $\mathrm{O}_{3}$ concentrations for $7-8 \mathrm{~h}$ in the daytime in summer, have demonstrated that $\mathrm{CH}_{4}$ emissions were reduced in response to the pollutant (e.g. Bhatia et al., 2011; Zheng et al., 2011), but not in all cases (Kou et al., 2015). However, none of these previous peatland or paddy studies have explored the impacts of the small year-round increases in $24 \mathrm{~h}$ mean background $\mathrm{O}_{3}$ concentrations that are now affecting many areas of the northern hemisphere (Royal Society, 2008), which may be significant since substantial $\mathrm{CH}_{4}$ emissions to the atmosphere have been reported in winter from boreal bogs and fens (e.g. Alm et al. 1999). Therefore, there is a need to assess year-round, long-term effects of elevated background annual mean $\mathrm{O}_{3}$ concentrations on $\mathrm{CH}_{4}$ emissions, as well as simply for summer peak exposures.

Furthermore, the mechanistic basis of any effects of $\mathrm{O}_{3}$ on $\mathrm{CH}_{4}$ emissions remains uncertain. It is unlikely to be related to direct effects of $\mathrm{O}_{3}$ on microbial populations belowground, because ${ }^{18} \mathrm{O}$ labelling studies have shown that $\mathrm{O}_{3}$ penetration into the soil is limited to the top few $\mathrm{mm}$, especially in wet soils (Toet et al., 2009). Consequently, $\mathrm{O}_{3}$ effects on microbial activity are more likely to be indirectly controlled by processes mediated through 
vascular plants. Although $\mathrm{O}_{3}$ has been reported to have little effect on above-ground biomass of peatland vegetation (Mörsky et al., 2011; Toet et al., 2011; Williamson et al., 2016), allocation of vascular plant biomass into below-ground components may be reduced (Ashmore, 2005), leading to reductions in substrate availability for methanogens. The potential for such effects was shown by Jones et al. (2009), who found a rapid decrease in dissolved organic carbon (DOC) concentrations in fen mesocosms after $\mathrm{O}_{3}$ exposure, with a change in molecular composition of DOC indicating a switch in the substrate for microorganisms from root-derived carbon $(\mathrm{C})$ to soil $\mathrm{C}$; similar effects were not found in mesocosms dominated by Sphagnum moss. Such indirect effects of elevated $\mathrm{O}_{3}$ in peatlands might be expected to affect $\mathrm{CH}_{4}$ production, although both Rinnan et al. (2003) and Mörsky et al. (2008) reported that elevated $\mathrm{O}_{3}$ had no significant effect on $\mathrm{CH}_{4}$ production potential.

Elevated $\mathrm{O}_{3}$ could also reduce $\mathrm{CH}_{4}$ emissions indirectly by impacts on $\mathrm{N}$ cycling. This may be through reduced litter quantity or quality, although effects of $\mathrm{O}_{3}$ on nitrification, denitrification, microbial biomass and plant uptake of $\mathrm{N}$ have also been reported (Wittig et al., 2009; Li et al. 2010; Bhatia et al., 2011; Pereira et al., 2011; Bassin et al., 2015). In nitrogen (N) poor systems such as peatlands, reduced below-ground allocation of $\mathrm{N}$ could cause reduced activity of heterotrophic soil microorganisms, such as methanogens (Kanerva et al., 2007). However, lower availability of ammonium $\left(\mathrm{NH}_{4}\right)$, the dominant form of inorganic $\mathrm{N}$ in peatlands, could also promote methanotrophic activity (Keller et al., 2006), and $\mathrm{O}_{3}$ has been reported to reduce soil $\mathrm{NH}_{4}$ concentrations in meadows (Kanerva et al. (2006) and soybean crops (Pereira et al., 2011). A direct adverse effect of $\mathrm{O}_{3}$ on methanotrophs in the top layers of the moss cover of peatlands may also play a role, with Raghoebarsing et al. (2005) showing $\mathrm{CH}_{4}$ consumption by Sphagnum plants through partly-endophytic methanotrophs in hyaline cells and on stem leaves.

We report here results from a peatland mesocosm study carried out over 2.5 years in open 
top chambers (OTCs), with two major aims. The first was to test the hypothesis that increases in global background $\mathrm{O}_{3}$ concentrations, as well as elevated $\mathrm{O}_{3}$ exposure during summertime, may reduce $\mathrm{CH}_{4}$ emissions from peatlands. Our second aim was to identify the mechanistic basis for any observed effects of elevated $\mathrm{O}_{3}$ concentrations on $\mathrm{CH}_{4}$ emissions, paying specific attention to the following hypotheses:-

1. Elevated $\mathrm{O}_{3}$ reduces plant $\mathrm{C}$ allocation below-ground, whilst not affecting overall above-ground plant productivity

2. Elevated $\mathrm{O}_{3}$ reduces the contribution of recent photosynthate to $\mathrm{CH}_{4}$ emission

3. Elevated $\mathrm{O}_{3}$ reduces $\mathrm{CH}_{4}$ production potentials

4. Elevated $\mathrm{O}_{3}$ decreases aerobic $\mathrm{CH}_{4}$ oxidation potentials associated with the top peat layer (including living Sphagnum moss)

5. Elevated $\mathrm{O}_{3}$ increases the aerobic $\mathrm{CH}_{4}$ oxidation potentials deeper down the peat profile due to reduced pore water $\mathrm{NH}_{4}$ concentrations.

\section{Materials and methods}

\subsection{Experimental design}

Mesocosms were collected from the wetter parts of a wet heath in the south western part of the Isle of Skye, Scotland (NGR: SV409227, latitude $57^{\circ} 13^{\prime} \mathrm{N}$, longitude $6^{\circ} 18^{\prime} \mathrm{W}, 16 \mathrm{~m}$ a.s.1.) where annual average air temperature was $6.6^{\circ} \mathrm{C}$ and annual average precipitation 2825 mm over the period 1981-2010. The vegetation was dominated by the peat moss Sphagnum papillosum and the sedge Schoenus nigricans, with Erica tetralix, Molinea caerulea and Narthecium ossifragum regularly present at very low abundance. Other species found 
intermittently and at very low abundance included Scirpus cespitosus, Eriophorum vaginatum, Drosera rotundifolia and other Sphagnum species such as S. recurvum and S. palustre.

Intact mesocosms (diameter $19 \mathrm{~cm}$, length $35 \mathrm{~cm}$ ) were cored in PVC tubes in early April 2008, sealed at the bottom and placed in deionised water in 22-1 containers (diameter $30.5 \mathrm{~cm})$. The water level was kept similar to the mean water table depth at the site by free drainage of the water through four 12-mm diameter holes $5 \mathrm{~cm}$ below the Sphagnum surface. The mesocosms were transported to the open-top chamber (OTC) facility, and left outside for a month to settle after coring; there was no evidence of significant damage to the vegetation as a result of cutting roots.

Ozone exposure was conducted in twelve rigid OTCs, situated at Heddon-on-the-Wall, Northumberland (NGR: NZ128659, latitude 545' $\mathrm{N}$, longitude $1^{\circ} 48^{\prime} \mathrm{W}, 25 \mathrm{~m}$ a.s.1.). The octagonal OTCs $(3.5 \mathrm{~m}(\max )$ diameter $\times 3.3 \mathrm{~m}$ tall $)$ and their $\mathrm{O}_{3}$ delivery and control systems are described in detail in Gonzalez-Fernandez et al. (2008). All OTCs were ventilated with non-filtered air (NFA) at a rate sufficient to achieve 2 air changes $\mathrm{min}^{-1}$. Twelve, of sixteen, OTCs were randomly assigned to one of four different $\mathrm{O}_{3}$ treatments (three OTCs per treatment). In addition to the 'ambient air' treatment, which received only NFA, we included one treatment which, as in our previous study (Toet et al., 2011) and in the studies of rice paddies, raised $\mathrm{O}_{3}$ levels for $8 \mathrm{~h}$ during summer daytime to NFA plus $35 \mathrm{ppb}$ (April - early October) and for $8 \mathrm{~h}$ during winter daytime to NFA plus $10 \mathrm{ppb}$ ('NFA+35/10'). The other two $\mathrm{O}_{3}$ treatments raised background $\mathrm{O}_{3}$ levels in the same range as the high $\mathrm{O}_{3}$ treatment, but $24 \mathrm{~h}$ throughout the year, to either NFA plus $10 \mathrm{ppb}\left({ }^{\prime} \mathrm{NFA}+10\right.$ '), corresponding to the upper end of IPCC predictions for 2050 under SRES scenarios (Wild et al., 2012), or to a more pessimistic NFA plus $25 \mathrm{ppb}$ ('NFA+25'). The use of $24 \mathrm{~h}$ exposures reflects the fact that, in rural areas throughout the $\mathrm{UK}, \mathrm{O}_{3}$ concentrations stay well above zero during the night and early morning (Royal Society 2008). 
Three mesocosms were randomly placed in each OTC on 6 May 2008, resulting in nine mesocosms per $\mathrm{O}_{3}$ treatment for the main experiment Additional mesocosms were placed in the OTCs for a ${ }^{13} \mathrm{CO}_{2}$ pulse-labelling experiment (see below). Methane emission, sedge green leaf density, soil temperature and pore water chemistry in all 36 mesocosms constituting the main experiment were determined prior to the start of $\mathrm{O}_{3}$ exposure. Methane emission rates (which were very low) and the other measured variables were not significantly different between the four groups of mesocosms assigned to each $\mathrm{O}_{3}$ treatment at the beginning of the experiment. The mesocosms were regularly rotated within the central part of each OTC to minimise any positional effects.

The effects of the OTCs on microclimatic conditions, determined from measurements made during the course of the experiment, were similar to those observed in other OTC studies (discussed in Toet et al. 2011). Precipitation was on average 14\% lower than outside and the mean air temperature within the OTCs was on average $1.3^{\circ} \mathrm{C}$ higher than outside. The much lower annual precipitation at the OTC facility than at the source field site was compensated by maintaining a prescribed water table depth in the mesocosms at a level comparable to the field site, by regular additions of deionised water. The air temperature outside the OTCs was on average $2.5^{\circ} \mathrm{C}$ higher than at the source field site. The higher temperature may have had some stimulating effect on plant and microbial activity of the mesocosms compared to the field situation, but the temperature increase was similar across all $\mathrm{O}_{3}$ treatments, whilst the water in the containers also reduced impacts of lateral heat fluxes on soil temperature.

\subsection{Main experiment}




\subsubsection{Methane emission}

Daytime methane emissions from all 36 mesocosms were measured 3-5 times each summer and three times each winter over the 2.5-year experiment, using the methods described by Toet et al. (2011). Briefly, static, opaque chambers $(25 \mathrm{~cm}$ high) covered with reflective insulation material to reduce temperature increases in the chamber during measurements were placed on the mesocosms, and gas samples $(20 \mathrm{ml})$ were collected from the headspace at regular intervals for periods of 80-120 min. and stored in evacuated 12-ml Exetainers (Labco Limited, High Wycombe, UK). The gas in the Exetainers was analysed for $\mathrm{CH}_{4}$ concentration on a PerkinElmer-Arnel gas chromatograph (GC, AutoSystem XL, PerkinElmer Instruments, Shelton, CT, USA) equipped with a flame ionization detector (FID) and a $3.7 \mathrm{~m}$ Porapak Q 60/80 mesh column within 7 days. Methane emission rates were calculated from the slope of regressions of $\mathrm{CH}_{4}$ concentrations with time in each chamber; regressions with $\mathrm{r}^{2}<0.90$ $(0.8 \%$ of the total) being rejected.

\subsubsection{Plant and soil variables}

Sedge green leaf density was determined for each mesocosm at each sampling date. Soil temperature was measured in each mesocosm at 2.5, 10 and $20 \mathrm{~cm}$ below the Sphagnum surface immediately after $\mathrm{CH}_{4}$ emission measurements using alcohol thermometers. Root biomass was determined at the end of the experiment in mesocosms exposed for 2.5 years to ambient $\mathrm{O}_{3}$ or NFA $+35 / 10$ only. A peat sample was collected over the entire length of the peat profile of each mesocosm. The volume of each peat sample was determined by water displacement to enable determination of the root biomass in the entire mesocosm. Roots were collected from each sample, dried at $70^{\circ} \mathrm{C}$ for two days, and weighed.

Peat water samples at 2.5, 10 and $20 \mathrm{~cm}$ below the Sphagnum surface were collected in each mesocosm on all sampling dates with Rhizon samplers (Eijkelkamp Agrisearch 
Equipment, Giesbeek, The Netherlands). The $\mathrm{pH}$ of each sample was measured (Thermo Orion 420Aplus, Thermo Orion Europe, Witchford, UK ), and each sample was analysed colorimetrically for $\mathrm{NH}_{4}$ and nitrate + nitrite $\left(\mathrm{NO}_{3}+\mathrm{NO}_{2}\right)$ using a Bran and Luebbe Autoanalyser 3 (Bran and Luebbe, Norderstedt, Germany), and for DOC using a TOC analyser (liquiTOC, Elementar Analysensysteme, Hanau, Germany).

Additional peat water samples were sampled via Rhizon samplers in 20-ml Exetainers from three mesocosms at each of the four $\mathrm{O}_{3}$ treatments at 2.5, 10, 20 and $30 \mathrm{~cm}$ depth on 29 July 2010 to determine the apparent fractionation factor $\left(\alpha_{C}\right)$ indicative of the predominant methanogenic pathway, i.e. acetoclastic or hydrogenotrophic methanogenesis (Conrad, 2005). Peat water samples were immediately acidified with $20 \%$ sulphuric acid and $\mathrm{N}_{2}$ was added to the headspace up to ambient pressure. The samples were left to equilibrate at $20^{\circ} \mathrm{C}$ for at least a week. Gas from the headspace was analysed for $\delta^{13} \mathrm{C}-\mathrm{CH}_{4}$ using a pre-concentrated cryofocussing isotope ratio mass spectrometer (GC-IRMS) setup described below (see ${ }^{13} \mathrm{CO}_{2}$ pulse-labelling experiment). The $\delta^{13} \mathrm{C}$ of the $\mathrm{CO}_{2}$ in gas samples was measured using the GCIRMS system described in Subke et al. (2009) consisting of an IRMS (SIRAS Series 2, Micromass, UK) with non-ionising electromagnetic radiation (NIER) type ion impact source and triple Faraday collector system employing a rotary/turbo-molecular pumping vacuum system, interfaced to a Microsoft Windows ${ }^{\mathrm{TM}}$ data system (model name 'PVS12', built by Pro-Vac Services, Crewe, UK). The apparent fractionation factor $\left(\alpha_{\mathrm{C}}\right)$ was calculated using the equation $\alpha_{\mathrm{C}}=\left(\delta^{13} \mathrm{CO}_{2}+10^{3}\right) /\left(\delta^{13} \mathrm{CH}_{4}+10^{3}\right)(\mathrm{Conrad}, 2005)$.

\subsubsection{Potential methane production and oxidation}

At the end of the experiment, potential $\mathrm{CH}_{4}$ production and oxidation were determined during a lab incubation in darkness at $19^{\circ} \mathrm{C}$ using a method adapted from Saarnio et al. (1998). Pilot experiments at different peat depths (0-5, 10-15 and 20-25 cm depth), showed that whilst 
potential aerobic $\mathrm{CH}_{4}$ oxidation occurred throughout the peat profile, potential $\mathrm{CH}_{4}$ production increased with depth (data not shown). Due to time constraints, the potential $\mathrm{CH}_{4}$ production and oxidation measurements in the four $\mathrm{O}_{3}$ treatments focussed on the top layer including green Sphagnum $(0-5 \mathrm{~cm})$ and the layer at $20-25 \mathrm{~cm}$ depth. The pilot tests were also used to identify over what incubation period the decrease or increase in $\mathrm{CH}_{4}$ concentration remained linear. Potential $\mathrm{CH}_{4}$ oxidation rates were also determined over a range of initial $\mathrm{CH}_{4}$ concentrations (20-10,000 ppm), with potential aerobic $\mathrm{CH}_{4}$ oxidation rates increasing with initial $\mathrm{CH}_{4}$ concentration, but not any further once the initial $\mathrm{CH}_{4}$ concentration exceeded 5,000 ppm. Therefore a starting $\mathrm{CH}_{4}$ concentration of 10,000 ppm was used at which $\mathrm{CH}_{4}$ oxidation was not limiting and which was similar to what was used for potential $\mathrm{CH}_{4}$ oxidation measurements of Sphagnum from peat bogs by Raghoebarsing et al. (2005) and Larmola et al. (2010).

For potential $\mathrm{CH}_{4}$ production measurements, a pooled subsample of the $20-25 \mathrm{~cm}$ layer from each mesocosm was immediately wrapped in aluminium foil and transferred to an anaerobic box flushed with $\mathrm{N}_{2}$ to keep soil conditions as anaerobic as possible. To $125-\mathrm{ml}$ Wheaton glass serum bottles (Wheaton UK, Rochdale, UK), $20 \mathrm{~g}$ of peat (after removal of large roots) and $10 \mathrm{ml}$ of oxygen-poor deionised water (flushed with $\mathrm{N}_{2}$ for $20 \mathrm{~min}$ ) were added. The headspace was flushed with $\mathrm{N}_{2}$ for 2 min before closing the bottle with a butyl rubber stopper and crimp cap. Three empty control bottles were also flushed with $\mathrm{N}_{2}$. Two minutes after adding another $10 \mathrm{ml}$ of $\mathrm{N}_{2}$ to each Wheaton bottle, $2 \mathrm{ml}$ of headspace was sampled from each bottle (t0) and stored in 3-ml evacuated Exetainers to which $5 \mathrm{ml}$ of $\mathrm{N}_{2}$ was added. The headspace was sampled daily over a 4-day incubation in the dark at $19^{\circ} \mathrm{C}$.

For potential aerobic $\mathrm{CH}_{4}$ oxidation measurements, pooled sub-samples of $20 \mathrm{~g}$ peat (and living moss, after removal of sedge shoots and large roots) from $0-5 \mathrm{~cm}$ or $20-25 \mathrm{~cm}$ depth were added to Wheaton bottles. The peat/moss was left to aerate in the bottles without 
septa overnight in the dark at $19^{\circ} \mathrm{C}$. The next morning, bottles were left outside for $15 \mathrm{~min}$ to establish ambient air headspace conditions and they were then sealed with crimped rubber stoppers. Another $10 \mathrm{ml}$ of air with concentrated $\mathrm{CH}_{4}$ was added, to create a start concentration of $10,000 \mathrm{ppm} \mathrm{CH}_{4}$ in the headspace. The headspace was sampled 2 min after adding the $\mathrm{CH}_{4}(\mathrm{t} 0)$ and again after 4, 8, 24 and 48 hours. Each time, $1 \mathrm{ml}$ of headspace was collected in 3-ml evacuated Exetainers and $6 \mathrm{ml} \mathrm{N} 2$ was added.

The gas samples were analysed for $\mathrm{CH}_{4}$ concentration on the gas chromatograph, as described earlier. The samples were also analysed for $\mathrm{CO}_{2}$ concentration to determine soil respiration under aerobic and anaerobic conditions. On the $\mathrm{GC}, \mathrm{CO}_{2}$ was first converted to $\mathrm{CH}_{4}$ before detection using FID by use of a Ni reduction catalyst. The rates of potential $\mathrm{CH}_{4}$ production and oxidation, and the rates of potential $\mathrm{CO}_{2}$ emission under anaerobic and aerobic conditions were determined from regressions, as described earlier in the text. The $\mathrm{r}^{2}$ of all the regressions exceeded 0.90 and therefore none were rejected. The amounts of $\mathrm{CH}_{4}$ and inorganic $\mathrm{C}$ dissolved in the water were also included in the flux calculations using Henry's law and the first dissociation constant of carbonic acid for dissolved inorganic C; for the latter the $\mathrm{pH}$ of the water was measured at the start and end of incubation and interpolated for the intermediate sampling times. No changes in $\mathrm{CH}_{4}$ and $\mathrm{CO}_{2}$ concentrations were observed in the control bottles during incubation.

\section{3. ${ }^{13} \mathrm{CO}_{2}$ pulse-labelling experiment}

Additional mesocosms that had been exposed to ambient $\mathrm{O}_{3}$ or $\mathrm{NFA}+35 / 10$ for 2.5 years were exposed to ${ }^{13} \mathrm{C}$ labelled $\mathrm{CO}_{2}$ during the daytime on 10 August 2010 to assess the effect of the two $\mathrm{O}_{3}$ treatments on the contribution of recent photosynthate to $\mathrm{CH}_{4}$ emission during a pulse-chase experiment. For each $\mathrm{O}_{3}$ treatment, nine mesocosms received a ${ }^{13} \mathrm{CO}_{2}$ pulse of 6.3 hours by enclosing the vegetation in each mesocosm using a transparent Perspex chamber 
(height $=25 \mathrm{~cm}$, internal diameter $=19.4 \mathrm{~cm}$ ) which received $380 \mathrm{ppm}{ }^{13} \mathrm{CO}_{2}$ in synthetic air (99 atom\%; Spectra Gases, Littleport, UK) at one air change every 2 min. A dark control mesocosm covered by dark and reflective material was also similarly exposed to ${ }^{13} \mathrm{CO}_{2}$ to take into account for any ${ }^{13} \mathrm{CO}_{2}$ diffusing into aerenchyma of the sedges or directly into the peat soil during the pulse, whilst a control mesocosm exposed to ambient air $\mathrm{CO}_{2}$ (natural abundance) was also included for each $\mathrm{O}_{3}$ treatment. A photoacoustic gas monitor (INNOVA 1412i, LumaSense Technologies, Ballerup, Denmark) was regularly connected to the outlet of chambers to check that the $\mathrm{CO}_{2}$ concentration within the chambers remained at ambient levels.

After the ${ }^{13} \mathrm{CO}_{2}$ pulse, $\mathrm{O}_{3}$ exposure of the mesocosms in the OTCs was continued for another 51 days. Methane emissions were determined the day before and 1, 3, 5, 7, 10, 14, 21, 30 and 51 days after the pulse as described earlier by sampling the headspace regularly over a $100 \mathrm{~min}$ period. At the end of the 100-min period, an additional $20 \mathrm{ml}$ gas sample was collected from the headspace and stored in a 12-ml Exetainer for subsequent ${ }^{13} \mathrm{C}-\mathrm{CH}_{4}$ analysis. Ambient air from each OTC was sampled in five Exetainers on each sampling date, which was transferred to a 100-ml Young's gas flask in the laboratory. Water was removed from these gas samples via a perchlorate chemical trap, and the $\mathrm{CH}_{4}$ was oxidised to $\mathrm{CO}_{2}$, which was cryogenically pre-concentrated using a trace gas pre-concentrator (Isoprime, Stockport, UK), prior to GC column (Poraplot Q) separation and introduction to an IRMS via open split (Isoprime, Stockport, UK) to determine the $\delta^{13} \mathrm{C}$ of the $\mathrm{CH}_{4}$ in the gas samples relative to V-PDB at the NERC Life Sciences Mass Spectrometry Facility, Lancaster (precision better than $0.5 \%$; instrument calibrated with NIST 8562 certified reference gas).

Methane emissions were determined through regressions over time as described previously (all regressions: $\mathrm{r}^{2}>0.90$ ). Cumulative $\mathrm{CH}_{4}$ emission over the entire 51-day chase period and the first 7 days was calculated using linear interpolation between sampling dates. 
The contribution of recently fixed $\mathrm{C}$ to the $\mathrm{CH}_{4}$ emitted from the mesocosms was determined by summation of the daily ${ }^{13} \mathrm{CH}_{4}$ emitted by the pulse using linear interpolation for days between sampling dates, and multiplying by the ratio of average day length (measured as when PAR in the OTCs was above $\left.50 \mu \mathrm{mol} \mathrm{m}^{-2} \mathrm{~s}^{-1}\right)$ and the length of the pulse (6.3 hours) on a weekly basis.

\subsection{Statistical analyses}

All data were analysed using IBM SPSS Statistics 20.0 (IBM Corp., Armonk, NY, USA). Data were tested for normality and log-transformed when variances were proportional to the means. Studentised residuals of statistical tests of the measured variables were screened for any OTC pattern within each $\mathrm{O}_{3}$ treatment or pattern in their position at the field station. No consistent OTC or position patterns were observed; consequently, statistical test results with the nine replicates per $\mathrm{O}_{3}$ treatment were used to interpret the data.

The effects of $\mathrm{O}_{3}$ and time on $\mathrm{CH}_{4}$ emission and ancillary variables were tested using linear mixed models. Data were analysed over the whole 2.5 -year period and additionally for the summer (April - early October) and winter (early October - March) periods separately. Sedge green leaf density was included as a covariate in the model if $p<0.100$. Multiple comparisons with Bonferroni correction were carried out amongst the means of the $\mathrm{O}_{3}$ treatments. An independent samples t-test was carried out to compare the difference in sedge root biomass between the $\mathrm{NFA}+35 / 10$ and ambient $\mathrm{O}_{3}$ treatments. Linear relationships between $\mathrm{CH}_{4}$ emission, sedge green leaf density and pore water variables were identified using Pearson's correlation tests during the summer and winter periods of the 2.5 year study, for all $\mathrm{O}_{3}$ treatments together and for individual $\mathrm{O}_{3}$ treatments.

A two-way ANOVA without replication with mesocosm as the second source was performed to determine the effect of peat depth on the apparent fractionation factor $\left(\alpha_{C}\right)$. 
Responses of aerobic $\mathrm{CH}_{4}$ oxidation potential to the four $\mathrm{O}_{3}$ treatments at two peat depths was tested using a two-way ANOVA, with OTC as a random factor nested within $\mathrm{O}_{3}$. For multiple comparisons among the means the Tukey test was used, and a modification of the standard error was calculated in the nested model (Zar, 1984). The same approach was used for $\mathrm{CH}_{4}$ production potential, but just for one peat depth.

The effects of $\mathrm{O}_{3}$ and time on the $\delta^{13} \mathrm{C}$ of the emitted $\mathrm{CH}_{4}$ during the chase was tested as described above, and independent samples t-tests were carried out to compare differences in sedge green leaf density and pore water variables between the NFA+35/10 and ambient $\mathrm{O}_{3}$ treatments.

\section{Results}

\section{1. $\mathrm{O}_{3}$ exposure}

The 24h mean $\mathrm{O}_{3}$ concentration in the ambient $\mathrm{O}_{3}$ treatment over the entire 2.5 year experiment (April 2008-August 2010) was 24 ppb, with little variation (23-26 ppb) between years and seasons (Table 1). The mean $\mathrm{O}_{3}$ concentration over the course of the experiment showed only a weak diurnal pattern, varying between $26.1 \mathrm{ppb}$ mid afternoon and $22.1 \mathrm{ppb}$ early morning (See Supplementary Information Figure S1). In NFA+10, the overall increase in $24 \mathrm{~h}$ mean concentration was $8 \mathrm{ppb}$, with a seasonal range of 7-10 ppb, except in the winter of 2008/9 when it was 2 ppb.

Table 1 Summary of $\mathrm{O}_{3}$ concentration treatments (ppb) in the OTCs with non-filter air (NFA: 'Ambient $\mathrm{O}_{3}$ '), NFA plus 10 ppb $\mathrm{O}_{3}$ ('NFA+10'), NFA plus 25 ppb $\mathrm{O}_{3}$ ('NFA+25') and NFA plus 35/10 $\mathrm{ppb} \mathrm{O}_{3}$ '(NFA+35/10') by season. All $\mathrm{O}_{3}$ treatments were supplied $24 \mathrm{~h}$ day ${ }^{-1}$, except for NFA+35/10, which was supplied for $8 \mathrm{~h}$ in the daytime (9:00-17:00) at NFA plus 
$35 \mathrm{ppb}$ during summer (April - early October) and at NFA plus $10 \mathrm{ppb}$ during winter (early October - March). (mean $\pm \mathrm{SE}, \mathrm{n}=3$ ).

\begin{tabular}{|c|c|c|c|c|c|}
\hline \multirow[t]{2}{*}{ season } & \multicolumn{4}{|c|}{$24 \mathrm{~h}$ mean $\mathrm{O}_{3}$ concentration } & \multirow{2}{*}{$\begin{array}{l}\text { 8h daytime } \\
\text { mean } \mathrm{O}_{3} \text { conc. } \\
\mathrm{NFA}+35 / 10\end{array}$} \\
\hline & Ambient $\mathrm{O}_{3}$ & $\mathrm{NFA}+10$ & $\mathrm{NFA}+25$ & $\mathrm{NFA}+35 / 10$ & \\
\hline summer 2008 & $26 \pm 1$ & $33 \pm 1$ & $47 \pm 1$ & $39 \pm 0$ & $62 \pm 1$ \\
\hline winter 2008/9 & $24 \pm 0$ & $26 \pm 1$ & $48 \pm 0$ & $31 \pm 0$ & $36 \pm 0$ \\
\hline summer 2009 & $24 \pm 0$ & $34 \pm 1$ & $59 \pm 0$ & $42 \pm 0$ & $64 \pm 0$ \\
\hline winter 2009/10 & $23 \pm 0$ & $32 \pm 0$ & $48 \pm 0$ & $27 \pm 0$ & $33 \pm 0$ \\
\hline summer 2010 & $24 \pm 0$ & $34 \pm 0$ & $53 \pm 0$ & $38 \pm 0$ & $61 \pm 0$ \\
\hline
\end{tabular}

In NFA+25, the overall increase of $27 \mathrm{ppb}$ was also close to the target, with a seasonal range of 22-29 ppb, except in the summer of 2009 when it was $35 \mathrm{ppb}$. The daytime $8 \mathrm{~h}$ mean $\mathrm{O}_{3}$ concentrations and the $24 \mathrm{~h}$ mean $\mathrm{O}_{3}$ concentrations were very similar for each of these treatments. The mean $8 \mathrm{~h}$-concentrations of the NFA+35/10 treatment ranged between 34 and $39 \mathrm{ppb}$ in summer and between 10 and $12 \mathrm{ppb}$ in winter. The overall increase in $24 \mathrm{~h}$ mean concentration in NFA+35/10 was 12 ppb overall (14-20 ppb in summers; 4-7 ppb in winters); hence in terms of $24 \mathrm{~h}$ mean concentrations this treatment lay between the NFA+10 and the NFA+25 treatments (Supplementary Information Table S2 for AOT40 values).

\subsection{Methane emission}

Reductions in $\mathrm{CH}_{4}$ emissions at elevated $\mathrm{O}_{3}$ were apparent from the end of July in the first growing season (Fig. 1). Methane emissions were significantly affected by $\mathrm{O}_{3}$ in summer 
over the entire 2.5 years of the experiment (Table 2). Summer $\mathrm{CH}_{4}$ emissions were reduced $(\mathrm{P}=0.06)$ by $27 \%$ in the NFA $+35 / 10$ treatment (Table 3$)$, but the effects of NFA +10 and $\mathrm{NFA}+25$ treatments were not statistically significant. Methane emissions were low in winter and there was no evidence of a significant $\mathrm{O}_{3}$ effect at this time (Table 2). In the third summer there appeared to be a consistent increase in $\mathrm{CH}_{4}$ emission in the NFA+10 treatment, but this effect was not significant.

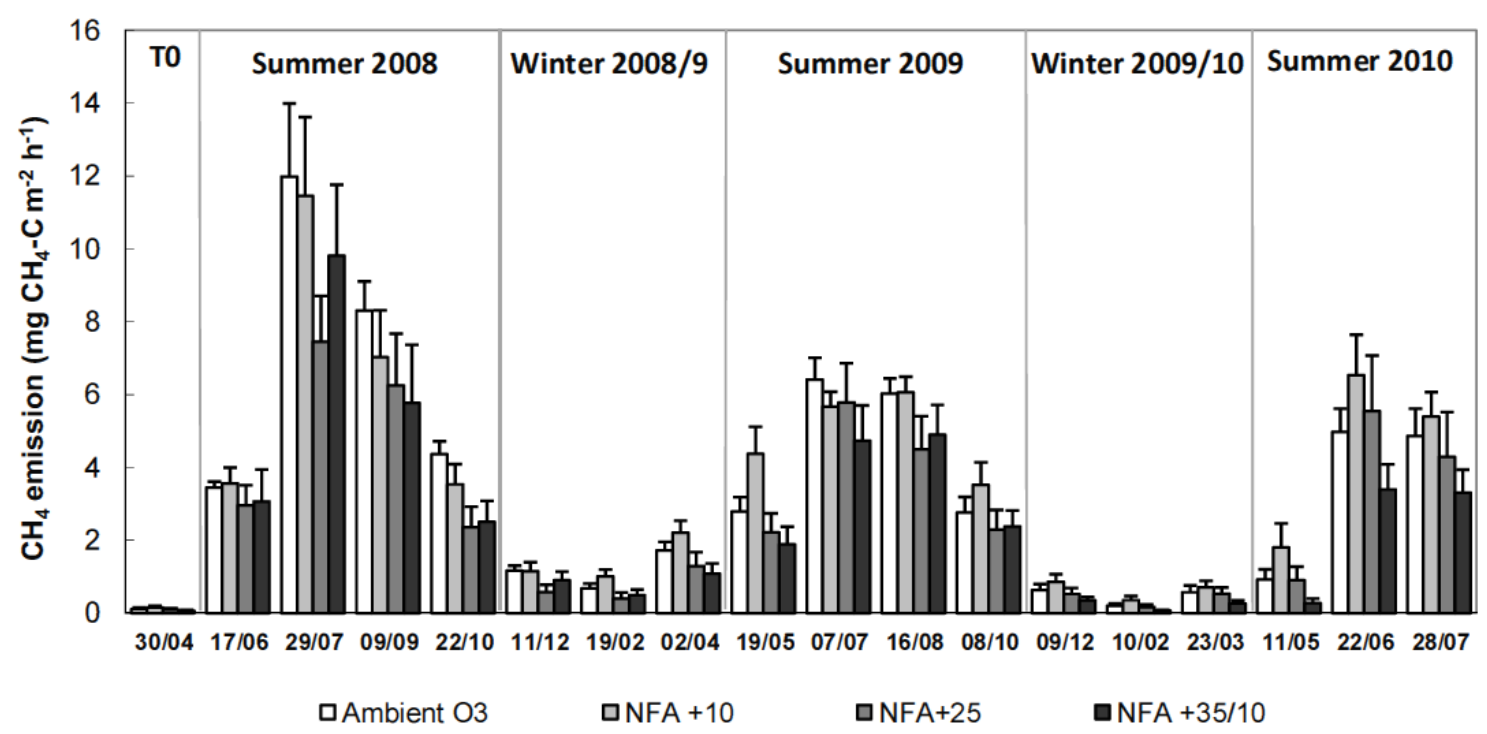

Fig. 1 Methane emission of wet heath mesocosms at ambient $\mathrm{O}_{3}$ (non-filtered air (NFA),

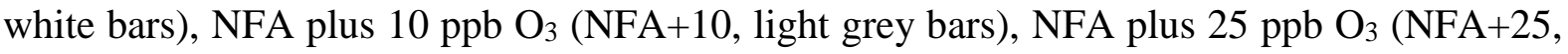
medium grey bars) and NFA plus 35/10 $\mathrm{ppb} \mathrm{O}_{3}(\mathrm{NFA}+35 / 10$, dark grey bars ppb) from April 2008 - July 2010. All $\mathrm{O}_{3}$ treatments were supplied $24 \mathrm{~h} \mathrm{day}^{-1}$, except for NFA+35/10, which was supplied for $8 \mathrm{~h}$ in the daytime (9:00-17:00) at NFA plus 35 ppb during summer (April early October) and at NFA plus 10 ppb during winter (early October - March). Values are expressed as mAean $\pm \mathrm{SE}(\mathrm{n}=9)$. See Table 2 for overview statistical analysis results. 
Table 2 Summary of statistical analysis of $\mathrm{O}_{3}$ effects on $\mathrm{CH}_{4}$ emission for the whole period, and for the three summer periods only or the two winter periods only (ozone: $n=9$; time: $n=$ 17, 11, 6 for the whole period, summers and winters only, respectively). Green sedge leaf density was only included as a covariate when $\mathrm{P}<0.100$.

\begin{tabular}{|c|c|c|c|c|c|c|c|c|}
\hline \multirow[t]{2}{*}{ period } & \multicolumn{2}{|c|}{ ozone } & \multicolumn{2}{|c|}{ time } & \multicolumn{2}{|c|}{ ozone*time } & \multicolumn{2}{|c|}{$\begin{array}{l}\text { leaf density } \\
\text { (covariate) }\end{array}$} \\
\hline & $\mathrm{F}$ & $P$ & $\mathrm{~F}$ & $\mathrm{P}$ & $\bar{F}$ & $P$ & $\mathrm{~F}$ & $P$ \\
\hline whole period & 2.30 & 0.096 & 51.10 & $<0.001$ & 3.32 & $<0.001$ & 3.25 & 0.075 \\
\hline summer & 3.22 & 0.036 & 72.78 & $<0.001$ & 1.58 & 0.104 & & \\
\hline winter & 1.69 & 0.191 & 21.83 & $<0.001$ & 1.56 & 0.143 & 6.74 & 0.011 \\
\hline
\end{tabular}

\subsection{Plant and soil variables}

Sedge green leaf density increased on average by $142 \%$ (SE: $\pm 25 \%$ ) from the first to the third summer, but was not significantly influenced by $\mathrm{O}_{3}$ (summers: $\mathrm{F}=0.04 \mathrm{P}=0.33$; winters: $\mathrm{F}=$ $0.35, \mathrm{P}=0.55$; Table 3). Sedge green leaf density was a significant covariate for $\mathrm{CH}_{4}$ emissions over the whole period and for the winter periods (Table 2). Methane emission was negatively correlated with sedge green leaf density during winter for all $\mathrm{O}_{3}$ treatments $(\mathrm{r}=$ $0.53 ; \mathrm{P}=0.001)$, and NFA+10 $(\mathrm{r}=-0.68, \mathrm{P}=0.04)$. At the end of the experiment, exposure to $\mathrm{NFA}+35 / 10$ had not significantly affected root biomass (mean $\pm \mathrm{SE}: 2593 \pm 307 \mathrm{~g} \mathrm{~m}^{-2}$ and $2378 \pm 172 \mathrm{~g} \mathrm{~m}^{-2}$ for ambient $\mathrm{O}_{3}$ and NFA+35/10, respectively; $\mathrm{t}=0.62 ; \mathrm{P}=0.55$ ). 
Table 3 Methane emission, sedge green leaf density, dissolved organic carbon (DOC) concentration, $\mathrm{pH}$ and $\mathrm{NH}_{4}-\mathrm{N}$ concentration of pore water at $20 \mathrm{~cm}$ depth at the four $\mathrm{O}_{3}$ treatments (see legend Table 1 for details of $\mathrm{O}_{3}$ treatments) by season averaged over the 2.5year study. Values are expressed as mean $\pm \mathrm{SE}(\mathrm{n}=9)$. Over the entire 2.5 -year period, $\mathrm{CH}_{4}$ emission $(\mathrm{P}<0.10)$ and pore water $\mathrm{NH}_{4}$ concentration at $20 \mathrm{~cm}$ depth $(\mathrm{P}<0.05)$ in summer were significantly lower at NFA+35/10 compared to ambient $\mathrm{O}_{3}$. Pore water $\mathrm{pH}$ at $20 \mathrm{~cm}$ depth was significantly lower at some of the sampling dates at elevated $\mathrm{O}_{3}(\mathrm{P}<0.05)$, whilst green leaf sedge density and pore water DOC concentration at $20 \mathrm{~cm}$ depth were not significantly affected by elevated $\mathrm{O}_{3}$ during the experiment.

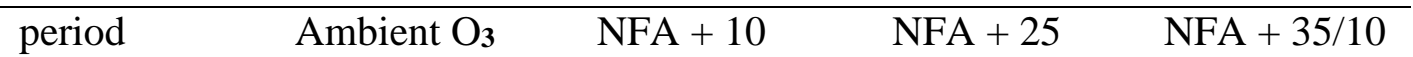

\section{$\underline{\mathrm{CH}_{4} \text { emission }\left(\mathrm{mg} \mathrm{C} \mathrm{m}^{-2} \mathrm{~h}^{-1}\right)}$}

$\begin{array}{lllll}\text { summer } & 4.47 \pm 0.30 & 4.98 \pm 0.41 & 3.87 \pm 0.75 & 3.27 \pm 0.58 \\ \text { winter } & 0.65 \pm 0.14 & 0.84 \pm 0.16 & 0.49 \pm 0.15 & 0.38 \pm 0.09\end{array}$

$\underline{\text { Sedge green leaf density (no. leaves } \mathrm{m}^{-2} \text { ) }}$

$\begin{array}{llrrr}\text { winter } & 4507 \pm 527 & 3353 \pm 588 & 4450 \pm 547 & 3897 \pm 365 \\ \text { winter } & 2804 \pm 348 & 1994 \pm 423 & 2596 \pm 320 & 2927 \pm 307\end{array}$

DOC concentration at $20 \mathrm{~cm}$ depth $\left(\mathrm{mg} \mathrm{l}^{-1}\right)$

$\begin{array}{llrrr}\text { summer } & 39.8 \pm 4.3 & 52.1 \pm 7.0 & 46.0 \pm 4.3 & 48.7 \pm 6.7 \\ \text { winter } & 20.4 \pm 1.8 & 32.4 \pm 6.8 & 24.5 \pm 2.0 & 19.1 \pm 2.0\end{array}$


$\underline{\mathrm{NH}_{4}-\mathrm{N} \text { concentration at } 20 \mathrm{~cm} \text { depth }\left(\mathrm{mg} \mathrm{l}^{-1}\right)}$

$\begin{array}{lllll}\text { summer } & 3.67 \pm 0.60 & 4.19 \pm 1.37 & 2.23 \pm 0.70 & 1.67 \pm 0.38 \\ \text { winter } & 3.22 \pm 0.52 & 3.33 \pm 1.15 & 2.24 \pm 0.86 & 1.53 \pm 0.40\end{array}$

$\mathrm{pH}$ at $20 \mathrm{~cm}$ depth

$\begin{array}{lllll}\text { summer } & 5.81 \pm 0.04 & 5.58 \pm 0.10 & 5.44 \pm 0.10 & 5.55 \pm 0.09 \\ \text { winter } & 5.85 \pm 0.07 & 5.75 \pm 0.10 & 5.56 \pm 0.04 & 5.65 \pm 0.09\end{array}$

The DOC concentration of the peat pore water at $20 \mathrm{~cm}$ below the Sphagnum surface did not respond significantly to the $\mathrm{O}_{3}$ treatments (summer: $\mathrm{F}=0.47, \mathrm{P}=0.70$; winter: $\mathrm{F}=1.43$, $\mathrm{P}=0.25$; Table 3), although the concentrations tended to be higher in the three elevated $\mathrm{O}_{3}$ treatments than for ambient $\mathrm{O}_{3}$. There were also no significant effects of $\mathrm{O}_{3}$ on $\mathrm{DOC}$ concentrations at $2.5 \mathrm{~cm}$ and $10 \mathrm{~cm}$ depth (data not shown).

In contrast, the effect of elevated $\mathrm{O}_{3}$ on $\mathrm{NH}_{4}$ concentrations in the pore water at $20 \mathrm{~cm}$ depth was significant in summer during the whole experiment $(\mathrm{P}=0.04$; Table 4$)$, but there was also a significant $\mathrm{O}_{3}$ *time interaction $(\mathrm{P}=0.007)$. The $\mathrm{O}_{3}$ effect, like that on $\mathrm{CH}_{4}$ emissions shown in Figure 1, became apparent from the first summer (Fig.2). During every summer, the $\mathrm{NH}_{4}$ concentrations were reduced significantly in NFA $+35 / 10$ compared to ambient $\mathrm{O}_{3}$ (by 50\% in $2008(\mathrm{P}<0.05)$, by 56\% in $2009(\mathrm{P}<0.05)$, and by $61 \%$ in $2010(\mathrm{P}<$ 0.10 ), with an overall reduction of $54 \%$ (Table 3; mean values $\pm \mathrm{SE}$ of $\mathrm{NH}_{4}-\mathrm{N}$ concentrations at $20 \mathrm{~cm}$ depth for each summer period are shown in the Supplementary Information: Table $\mathrm{S} 3$ ). The $\mathrm{NH}_{4}-\mathrm{N}$ concentrations were also reduced in the two other elevated $\mathrm{O}_{3}$ treatments during the first summer $(\mathrm{P}<0.10)$, and for NFA+25 also in summer $2009(\mathrm{P}<0.10)$. Overall in winter, the $\mathrm{NH}_{4}$ concentrations at $20 \mathrm{~cm}$ were reduced by $52 \%$ in NFA+35/10 $(\mathrm{P}<0.10$; Table 3). Like $\mathrm{CH}_{4}$ emissions, $\mathrm{NH}_{4}$ concentrations tended to become higher in NFA+10 than 
ambient $\mathrm{O}_{3}$ treatments in the final year of the experiment (Fig. 2), but this effect was not significant. Elevated $\mathrm{O}_{3}$ did not significantly affect pore water $\mathrm{NH}_{4}$ concentrations at $2.5 \mathrm{~cm}$ and $10 \mathrm{~cm}$ depth, although similar trends in response to $\mathrm{O}_{3}$ were observed (data not shown). The $\mathrm{NO}_{3}+\mathrm{NO}_{2}$ concentrations in pore water were in general consistently very low throughout the peat profile.

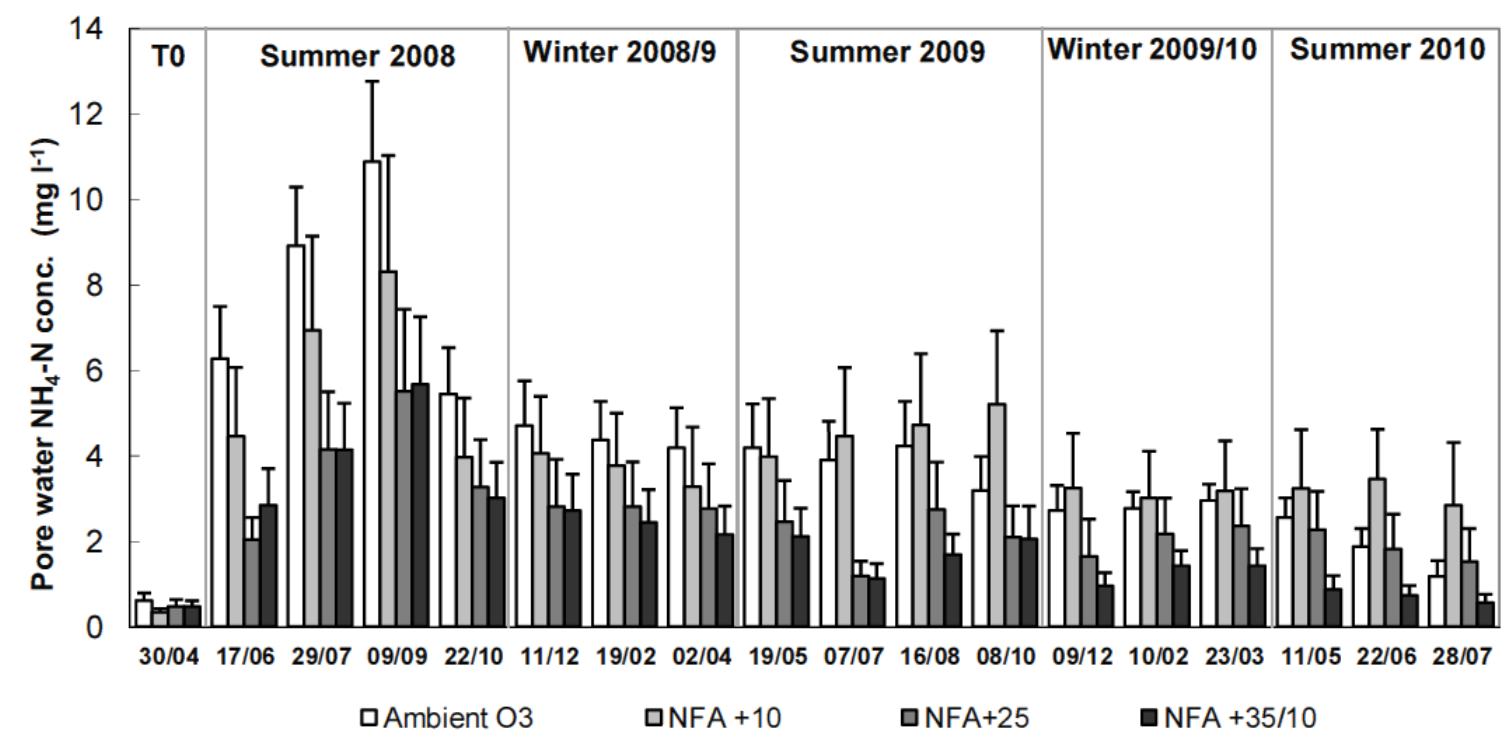

Fig. 2 Ammonium concentration of pore water at $20 \mathrm{~cm}$ below the moss surface of wet heath mesocosms at four $\mathrm{O}_{3}$ treatments (see legend Fig. 1 for details of $\mathrm{O}_{3}$ treatments) from April 2008 - July 2010. Values are expressed as mean \pm SE $(n=9)$. See Table 4 for overview statistical analysis results.

Table 4 Summary of statistical analysis of $\mathrm{O}_{3}$ effects on $\mathrm{NH}_{4}$ concentration of pore water at $20 \mathrm{~cm}$ below the moss surface for the whole period, and for the three summer periods only or the two winter periods only (ozone: $n=9$; time: $n=17,11,6$ for the whole period, summer and winter only, respectively). Green sedge leaf density was only included as a covariate when $\mathrm{P}<0.100$. 


\begin{tabular}{|c|c|c|c|c|c|c|c|c|}
\hline \multirow[t]{2}{*}{ period } & \multicolumn{2}{|c|}{ ozone } & \multicolumn{2}{|c|}{ time } & \multicolumn{2}{|c|}{ ozone*time } & \multicolumn{2}{|c|}{$\begin{array}{l}\text { leaf density } \\
\text { (covariate) }\end{array}$} \\
\hline & $\mathrm{F}$ & $\mathrm{P}$ & $\mathrm{F}$ & $\mathrm{P}$ & $\mathrm{F}$ & $\mathrm{P}$ & $\mathrm{F}$ & $\mathrm{P}$ \\
\hline whole & 2.44 & 0.063 & 48.54 & $<0.001$ & 2.17 & 0.012 & 12.38 & 0.001 \\
\hline \multicolumn{9}{|l|}{ period } \\
\hline summer & 3.04 & 0.043 & 29.43 & $<0.001$ & 2.42 & 0.007 & 23.67 & $<0.001$ \\
\hline winter & 1.96 & 0.142 & 3.05 & 0.022 & 1.00 & 0.480 & 14.25 & $<0.001$ \\
\hline
\end{tabular}

The $\mathrm{pH}$ of pore water at $20 \mathrm{~cm}$ was significantly affected by $\mathrm{O}_{3}$ during the summer periods ( $\mathrm{F}=3.58, \mathrm{P}=0.02$; Table 3$)$ throughout the experiment, but only during the second of the winter periods $(\mathrm{F}=3.05, \mathrm{P}=0.043)$. There was also a highly significant interaction of $\mathrm{O}_{3}$ with time in summer $(\mathrm{F}=3.63, \mathrm{P}<0.001)$ which was also present for the first two individual summer periods; $\mathrm{pH}$ was significantly lower in NFA+10 than ambient $\mathrm{O}_{3}$ on three summer measurement dates, and significantly lower in $\mathrm{NFA}+35 / 10$ than ambient $\mathrm{O}_{3}$ on five. During the second winter, $\mathrm{pH}$ was also significantly lower at $\mathrm{NFA}+25(\mathrm{P}<0.05)$. Similar $\mathrm{O}_{3}$ effects were observed for $\mathrm{pH}$ at $10 \mathrm{~cm}$ and $2.5 \mathrm{~cm}$, though the effects were significant at fewer sampling dates (data not shown).

Pore water $\mathrm{NH}_{4}$ concentrations at all three depths were positively correlated with $\mathrm{CH}_{4}$ emissions in both summer and winter when data for all $\mathrm{O}_{3}$ treatments were included (Table 5). At the two deeper depths, this was also the case for the NFA+35/10 treatment in summer and winter, and for most other $\mathrm{O}_{3}$ treatments in winter (data not shown). Pore water $\mathrm{pH}$ also correlated positively with $\mathrm{CH}_{4}$ emission when all $\mathrm{O}_{3}$ treatments were included; this effect was significant in the winters throughout the peat profile, and in the summers at $10 \mathrm{~cm}$ and $20 \mathrm{~cm}$ depth (Table 5). At the two deeper depths, significant positive correlations were also 
frequently found for individual $\mathrm{O}_{3}$ treatments, particularly in winter (data not shown). The $\mathrm{pH}$ always showed strong significant positive correlations with $\mathrm{NH}_{4}$ concentrations at each depth $(0.001<\mathrm{P}<0.002)$.

Table 5 Pearson correlation coefficients (r) and associated P-values of methane emission (mg $\mathrm{C} \mathrm{m}^{-2} \mathrm{~h}^{-1}$ ) with pore water $\mathrm{NH}_{4}-\mathrm{N}$ concentration $\left(\mathrm{mg} \mathrm{l}^{-1}\right)$ and $\mathrm{pH}$ at 2.5, 10 and $20 \mathrm{~cm}$ below the Sphagnum surface $(\mathrm{n}=36)$, across all $\mathrm{O}_{3}$ treatments split by summer and winter impacts during the 2.5-year study $(\mathrm{n}=36)$. Significant correlations $(\mathrm{P}<0.05)$ are indicated in bold. Untransformed data were used, except for $\mathrm{NH}_{4}-\mathrm{N}$ concentrations at all three depths in summer, and at $2 \mathrm{~cm}$ and $10 \mathrm{~cm}$ depth in winter.

\begin{tabular}{|c|c|c|c|}
\hline \multirow[t]{2}{*}{ period } & $2.5 \mathrm{~cm}$ depth & $10 \mathrm{~cm}$ depth & $20 \mathrm{~cm}$ depth \\
\hline & $\mathrm{P}$ & $\mathrm{P}$ & $\mathrm{P}$ \\
\hline
\end{tabular}

\section{$\underline{\mathrm{NH}_{4}-\mathrm{N}}$}

$\begin{array}{lllllll}\text { summer } & \mathbf{0 . 4 9 6} & \mathbf{0 . 0 0 2} & \mathbf{0 . 6 4 9} & <\mathbf{0 . 0 0 1} & \mathbf{0 . 6 7 3} & <\mathbf{0 . 0 0 1} \\ \text { winter } & \mathbf{0 . 6 0 9} & <\mathbf{0 . 0 0 1} & \mathbf{0 . 6 5 3} & <\mathbf{0 . 0 0 1} & \mathbf{0 . 6 2 6} & <0.001\end{array}$

$\underline{\mathrm{pH}}$

$\begin{array}{lllllll}\text { summer } & 0.188 & 0.271 & \mathbf{0 . 3 9 0} & \mathbf{0 . 0 1 9} & \mathbf{0 . 4 6 9} & \mathbf{0 . 0 0 4} \\ \text { winter } & \mathbf{0 . 3 5 2} & \mathbf{0 . 0 3 5} & \mathbf{0 . 6 4 8} & <\mathbf{0 . 0 0 1} & \mathbf{0 . 4 5 5} & \mathbf{0 . 0 0 5}\end{array}$

Soil temperature at $2.5 \mathrm{~cm}$ in summer, and at $10 \mathrm{~cm}$ in both summer and winter, showed significant overall $\mathrm{O}_{3}$ treatment differences. However, the soil temperature differences between elevated $\mathrm{O}_{3}$ treatments and ambient $\mathrm{O}_{3}$ were not consistent over time at 
2.5 and $20 \mathrm{~cm}$, ranging between -0.4 and $0.7^{\circ} \mathrm{C}$ at $2.5 \mathrm{~cm}$ depth, and between -0.1 and $0.3^{\circ} \mathrm{C}$ at $20 \mathrm{~cm}$ depth. There were more consistent soil temperature differences $(\mathrm{P}<0.10)$ at $10 \mathrm{~cm}$ depth, with soil temperature in NFA+10 in summer and NFA+35/10 in winter being $0.5^{\circ} \mathrm{C}$ higher than at ambient $\mathrm{O}_{3}$. Overall, soil temperature differences between elevated $\mathrm{O}_{3}$ treatments and ambient $\mathrm{O}_{3}$ at $10 \mathrm{~cm}$ depth ranged between -0.1 and $0.5^{\circ} \mathrm{C}$ in summer and between $0.1^{\circ} \mathrm{C}$ and $0.5^{\circ} \mathrm{C}$ in winter.

\section{4. ${ }^{13} \mathrm{CO}_{2}$ pulse labelling experiment}

The $\delta^{13} \mathrm{C}$ of the emitted $\mathrm{CH}_{4}$ was enhanced one day after the application of the ${ }^{13} \mathrm{CO}_{2}$ pulse, peaked after 10-14 days, and then gradually decreased again (time effect: $\mathrm{F}=63.67, \mathrm{P}<0.001$; Fig. 3). However, the $\delta^{13} \mathrm{C}-\mathrm{CH}_{4}$ value was not significantly affected by $\mathrm{O}_{3}$ over the 51 days of the experiment $(\mathrm{F}=0.29, \mathrm{P}=0.59)$, and there was no significant $\mathrm{O}_{3} *$ time interaction $(\mathrm{F}=0.15$, $\mathrm{P}=1.00)$. Sedge green leaf density was included in the model $(\mathrm{F}=103.0, \mathrm{P}<0.001)$.

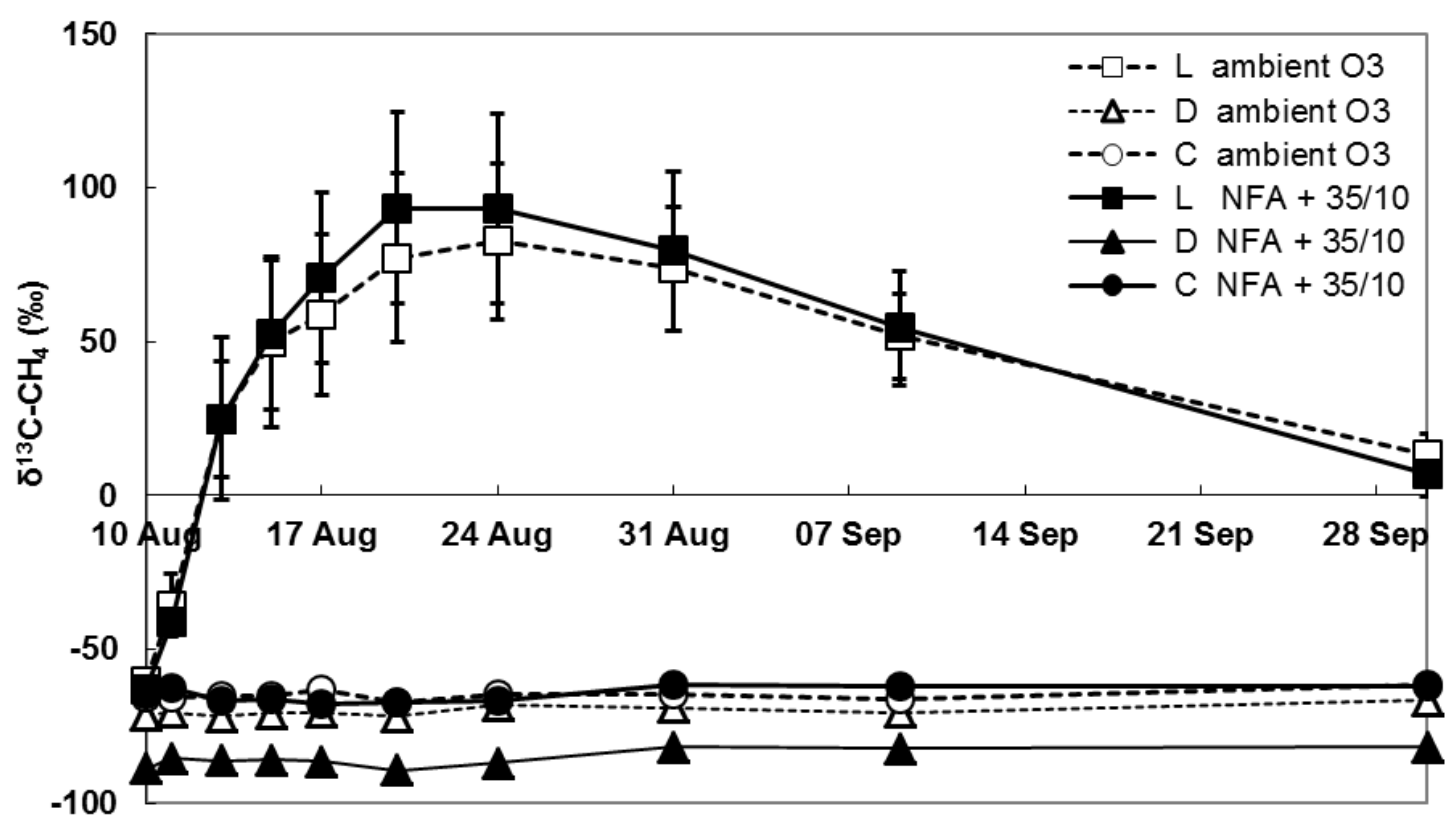


Fig. 3 The $\delta^{13} \mathrm{C}$ of the emitted $\mathrm{CH}_{4}$ after the ${ }^{13} \mathrm{CO}_{2}$ pulse labelling of $6.3 \mathrm{~h}$ hours on 10 August 2010 at ambient $\mathrm{O}_{3}$ and NFA+35/10 (see legend Fig. 1 for details of $\mathrm{O}_{3}$ treatments), using transparent chambers during the ${ }^{13} \mathrm{CO}_{2}$ pulse in ambient light $(\mathrm{L})$, identical transparent chambers with $\mathrm{CO}_{2}$ at natural abundance in ambient light ('light controls', C), and identical but opaque chambers during the ${ }^{13} \mathrm{CO}_{2}$ pulse in dark conditions ('dark controls', D). For L: values are expressed as mean $\pm \operatorname{SE}(n=9)$, For $C$ and $D$ controls: $n=1$. No significant difference between ambient $\mathrm{O}_{3}$ and the NFA+35/10 treatments was observed at $\mathrm{P}<0.05$.

The contribution of recent photosynthate to $\mathrm{CH}_{4}$ emission over the 51-day period was not significantly affected by $\mathrm{O}_{3}(\mathrm{t}=-0.24, \mathrm{P}=0.81)$ and was relatively small (on average $12 \%$ for both $\mathrm{O}_{3}$ treatments; Table 6). Little ${ }^{13} \mathrm{CH}_{4}$ was emitted from the dark control mesocosms after the ${ }^{13} \mathrm{CO}_{2}$ pulse (contribution of recent photosynthates to $\mathrm{CH}_{4}$ emission: $0.1-0.4 \%$ ), confirming that the ${ }^{13} \mathrm{CH}_{4}$ emitted in light conditions was predominantly derived from newly fixed $\mathrm{C}$.

Table 6 Cumulative $\mathrm{CH}_{4}$ emission, and plant and soil chemistry variables of the wet heath mesocosms of the ${ }^{13} \mathrm{CO}_{2}$ pulse labelling experiment at ambient $\mathrm{O}_{3}$ and $\mathrm{NFA}+35 / 10$ treatments (see legend Table 1 for details of $\mathrm{O}_{3}$ treatments). ' $-5 \mathrm{~cm}$ ' and ' $-20 \mathrm{~cm}$ ' are measurements at 5 and $20 \mathrm{~cm}$ below the Sphagnum surface, respectively. Values are expressed as mean $\pm S E(n=9)$. Significant correlations $(P<0.10)$ are indicated in bold.

\begin{tabular}{lll}
\hline variable & Ambient $\mathrm{O}_{3}$ & $\mathrm{NFA}+35 / 10$
\end{tabular}

\section{$\left.\underline{\mathrm{CH}}_{4} \underline{\text { emission }} \mathrm{mg} \mathrm{CH}{ }_{4}-\mathrm{C} \mathrm{m}^{-2} \mathrm{~h}^{-1}\right)$}
0-7 days
$4.27 \pm 0.48$
$3.09 \pm 0.46$ 
Contribution of recent photosynthates to $\mathrm{CH}_{4}$ emission (\%)
0-51 days
$11.7 \pm 1.8$
$12.4 \pm 2.3$

$\underline{\text { Sedge green leaf density (no. leaves } \mathrm{m}^{-2} \text { ) }}$

day 0

$4852 \pm 1365 \quad 4562 \pm 1016$

$\underline{\text { Pore water chemistry at day } 0 \text { (concentrations in } \mathrm{mg}^{-1} \text { ) }}$

$\begin{array}{lcc}\text { NH}_{4}-\mathrm{N} \text { conc.: } 2.5 \mathrm{~cm} \text { depth } & 0.10 \pm 0.04 & 0.16 \pm 0.05 \\ \text { NH4-N conc.: } 20 \mathrm{~cm} \text { depth } & 2.76 \pm 0.99 & 2.08 \pm 0.84 \\ \text { DOC conc.: } 2.5 \mathrm{~cm} \text { depth } & \mathbf{8 . 4} \pm \mathbf{0 . 5} & \mathbf{1 2 . 1} \pm \mathbf{2 . 0} \\ \text { DOC conc.: } 20 \mathrm{~cm} \text { depth } & 19.5 \pm 3.4 & 25.9 \pm 7.4 \\ \text { pH: } 2.5 \mathrm{~cm} \text { depth } & 5.37 \pm 0.04 & 5.41 \pm 0.06 \\ \text { pH: } 20 \mathrm{~cm} \text { depth } & 5.66 \pm 0.04 & 5.60 \pm 0.09\end{array}$

Cumulative $\mathrm{CH}_{4}$ emission over 0-7 days was $28 \%$ lower in the NFA+35/10 treatment $(\mathrm{t}=1.83, \mathrm{P}=0.09)$, but this effect was not significant over days $0-51(\mathrm{~F}=1.34, \mathrm{P}=0.20)$. The effects of the NFA+35/10 treatment on sedge green leaf density and pore water chemistry are also summarised in Table 6; there were no significant $\mathrm{O}_{3}$ effects except for DOC at $2.5 \mathrm{~cm}$ depth which tended to be higher at NFA+35/10 $(\mathrm{t}=1.81, \mathrm{P}=0.09)$.

\subsection{Predominant methanogenic pathway}

The apparent fractionation factor $\left(\alpha_{C}\right)$ was significantly lower at $2.5 \mathrm{~cm}$ and $10 \mathrm{~cm}$ (mean \pm SE: $1.048 \pm 0.001$ and $1.049 \pm 0.001)$ than at $20 \mathrm{~cm}$ and $30 \mathrm{~cm}$ depth $(1.055 \pm 0.001$ and 
$1.057 \pm 0.001$; depth effect: $\mathrm{F}=17.61, \mathrm{P}<0.001)$. There was no significant effect of $\mathrm{O}_{3}$.

\subsection{Potential methane production and oxidation}

The overall effect of $\mathrm{O}_{3}$ on $\mathrm{CH}_{4}$ production potential was highly significant $(\mathrm{F}=8.29, \mathrm{P}=0.01$; Fig. 4a). The $\mathrm{CH}_{4}$ production potential in NFA+10 was reduced by $44 \%$ compared to ambient $\mathrm{O}_{3}$, while that in NFA+25 was reduced by $61 \%$; post-hoc tests showed that both these effects were significant $(\mathrm{P}<0.05)$. However, the $\mathrm{CH}_{4}$ production potential in $\mathrm{NFA}+35 / 10$ was only reduced by $22 \%$, a value that was not significantly lower than ambient $\mathrm{O}_{3}$.

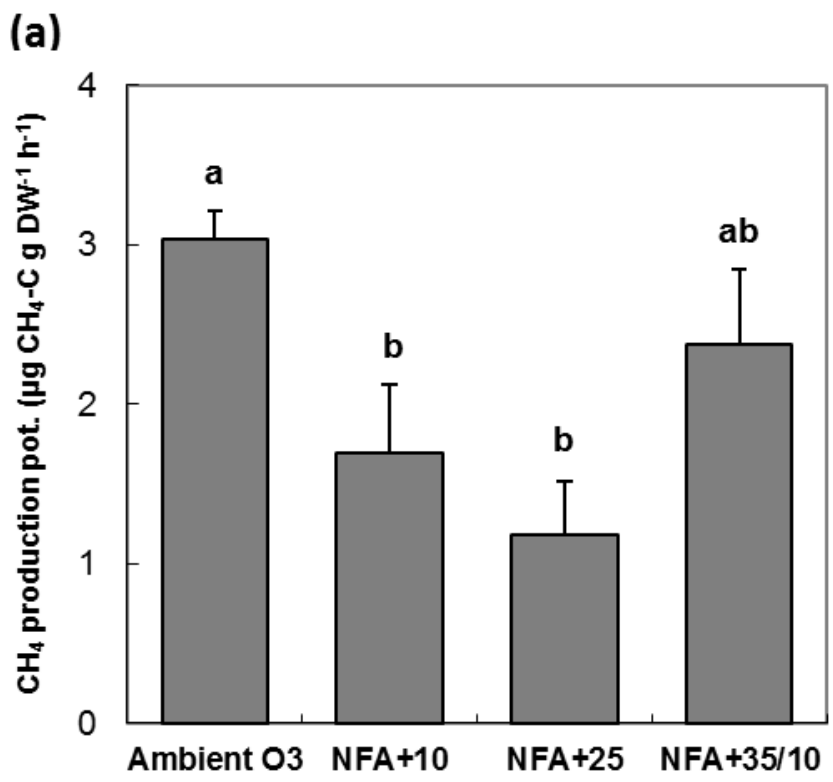




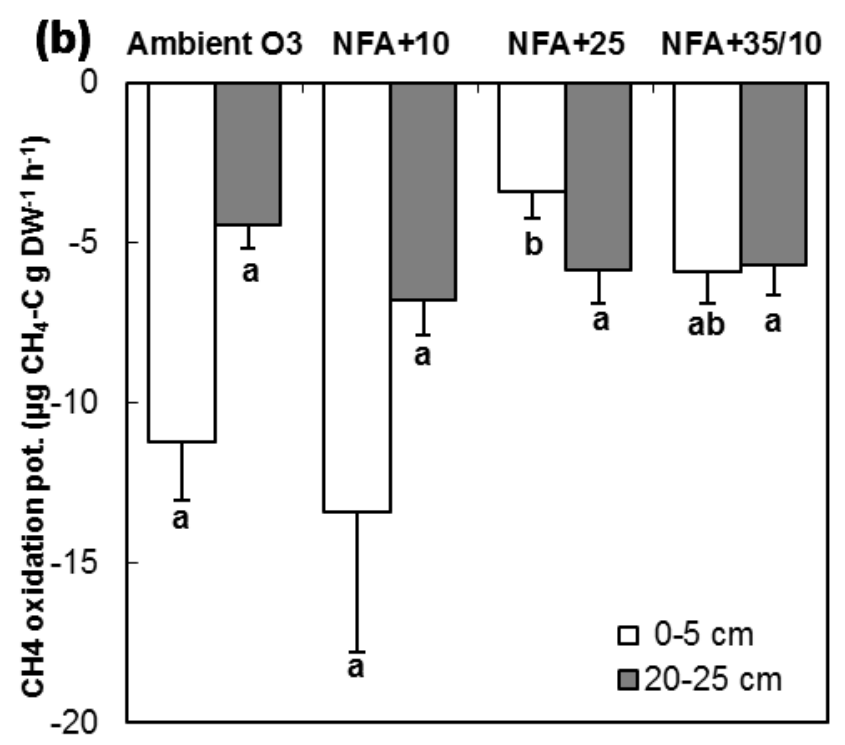

Fig. 4 Methane production potential at 20-25 cm below the Sphagnum surface (a) and aerobic $\mathrm{CH}_{4}$ oxidation potential at $0-5 \mathrm{~cm}$ (white bars) and 20-25 cm (grey bars) depth below the Sphagnum surface (b) at the four $\mathrm{O}_{3}$ treatments in August 2010 (see legend Fig. 1 for details of $\mathrm{O}_{3}$ treatments). Values are expressed as mean $\pm \mathrm{SE}(\mathrm{n}=9)$. Letters indicate significant differences among $\mathrm{O}_{3}$ treatments within the same soil depth at $\mathrm{P}<0.05$.

The aerobic $\mathrm{CH}_{4}$ oxidation potential was significantly reduced by elevated $\mathrm{O}_{3}$ in the top $5 \mathrm{~cm}$ of the mesocosms $(\mathrm{F}=14.94, \mathrm{P}=0.001$; Fig. $4 \mathrm{~b})$; the values were reduced by $70 \%$ $(\mathrm{P}<0.05)$ and $56 \%(\mathrm{P}<0.10)$ in NFA+25 and NFA+35/10 respectively, compared to ambient $\mathrm{O}_{3}$. However, there was no significant $\mathrm{O}_{3}$ effect at $20-25 \mathrm{~cm}(\mathrm{~F}=0.64, \mathrm{P}=0.61)$.

Table 7 summarises $\mathrm{O}_{3}$ effects on other variables in these mesocosms. Anaerobic respiration at $20-25 \mathrm{~cm}$ was not affected by $\mathrm{O}_{3}(\mathrm{~F}=0.78, \mathrm{P}=0.53)$, nor was aerobic respiration measured at $0-5 \mathrm{~cm}$ and $20-25 \mathrm{~cm}$ (overall: $\mathrm{F}=1.11, \mathrm{P}=0.40$ ). Sedge green leaf density was affected by $\mathrm{O}_{3}(\mathrm{~F}=3.60, \mathrm{P}=0.07)$, with values in the three elevated $\mathrm{O}_{3}$ treatments tending to be lower than at ambient $\mathrm{O}_{3}$ (only for $\mathrm{NFA}+10$ : $\mathrm{P}<0.10$ ). Extractable $\mathrm{NH}_{4}$ concentrations at $20 \mathrm{~cm}$ had a tendency to decline with increasing $\mathrm{O}_{3}$, and pore water DOC 
concentration at both depths tended to be higher at elevated $\mathrm{O}_{3}$, but neither of these effects was significant. Soil $\mathrm{pH}$ was not significantly affected by $\mathrm{O}_{3}$ at $20 \mathrm{~cm}$, but there was a significant effect at $2.5 \mathrm{~cm}$ depth $\left(\mathrm{O}_{3}: \mathrm{F}=3.04, \mathrm{P}<0.05\right)$, with significantly lower values in $\mathrm{NFA}+25$ than at NFA+35/10.

Table 7 Soil respiration rates, and plant and soil chemistry variables of peat incubations used for $\mathrm{CH}_{4}$ production and aerobic $\mathrm{CH}_{4}$ oxidation potentials at the four different $\mathrm{O}_{3}$ treatments (see legend Table 1 for details of $\mathrm{O}_{3}$ treatments) in August 2010. Values are expressed as mean $\pm \mathrm{SE}(n=9)$. Anaerobic and aerobic respiration, extractable $\mathrm{NH}_{4}$ concentration at 20-25 cm depth and most pore water variables were not significantly affected by elevated $\mathrm{O}_{3}$, except for sedge green leaf density which was lower at the three elevated $\mathrm{O}_{3}$ treatments $(\mathrm{P}<$ 0.10 ), and for pore water $\mathrm{pH}$ at $2.5 \mathrm{~cm}$ depth which was significantly lower at NFA+25 than at NFA+35/10 $(\mathrm{P}<0.05)$.

\begin{tabular}{|c|c|c|c|c|}
\hline variable & Ambient $\mathrm{O}_{3}$ & $\mathrm{NFA}+10$ & $\mathrm{NFA}+25$ & $\mathrm{NFA}+35 / 10$ \\
\hline
\end{tabular}

$\underline{\text { Anaerobic respiration }(\mu \mathrm{g} \mathrm{CO}} 2 \underline{\left.\mathrm{Cg} \mathrm{DW}^{-1} \mathrm{~h}^{-1}\right)}$
$20-25 \mathrm{~cm}$ depth
$6.4 \pm 0.4$
$6.5 \pm 0.8$
$7.3 \pm 0.8$
$6.3 \pm 0.9$

$\underline{\text { Aerobic respiration }\left(\mu \mathrm{g} \mathrm{CO} \mathrm{CO}_{2}-\mathrm{Cg} \mathrm{DW}^{-1} \mathrm{~h}^{-1}\right)}$
0-5 cm depth
$31.8 \pm 2.3$
$36.7 \pm 2.0$
$35.4 \pm 4.0$
$31.6 \pm 1.1$
20-25 cm depth
$12.0 \pm 0.6$
$14.9 \pm 0.9$
$13.8 \pm 1.3$
$14.0 \pm 1.2$

$\underline{\text { Sedge green leaf density (no. leaves } \mathrm{m}^{-2} \text { ) }}$ 


$7058 \pm 959 \quad 4204 \pm 1352 \quad 5829 \pm 846 \quad 4999 \pm 542$

$\underline{\text { Pore water chemistry (concentrations in } \mathrm{mg}^{-1} \text { ) }}$

$\begin{array}{lcccc}\mathrm{NH}_{4}-\mathrm{N} \text { conc.: } 2.5 \mathrm{~cm} \text { depth } & 0.02 \pm 0.01 & 0.24 \pm 0.18 & 0.05 \pm 0.04 & 0.02 \pm 0.01 \\ \text { NH4-N conc.: } 20 \mathrm{~cm} \text { depth } & 1.18 \pm 0.37 & 2.85 \pm 1.47 & 1.52 \pm 0.78 & 0.56 \pm 0.20 \\ \text { DOC conc.: } 2.5 \mathrm{~cm} \text { depth } & 9.5 \pm 1.4 & 14.6 \pm 2.4 & 15.2 \pm 2.9 & 14.8 \pm 3.4 \\ \text { DOC conc.: } 20 \mathrm{~cm} \text { depth } & 21.0 \pm 3.4 & 34.9 \pm 6.7 & 31.6 \pm 3.7 & 35.2 \pm 9.4 \\ \text { pH: } 2.5 \text { cm depth } & 5.35 \pm 0.09 & 5.36 \pm 0.10 & 5.08 \pm 0.09 & 5.47 \pm 0.10 \\ \text { pH: } 20 \mathrm{~cm} \text { depth } & 5.69 \pm 0.04 & 5.53 \pm 0.08 & 5.48 \pm 0.11 & 5.49 \pm 0.05\end{array}$

$\underline{\text { Extractable } \mathrm{NH}_{4}-\mathrm{N} \text { concentration }\left(0.5 \mathrm{M} \mathrm{NaCl} \text {; in } \mathrm{mg} \mathrm{kg}^{-1} \mathrm{DW}\right)}$

20-25 cm depth $\quad 101 \pm 10 \quad 86.0 \pm 22.4 \quad 74.1 \pm 21.7 \quad 64.5 \pm 11.5$

\section{Discussion}

\subsection{Ozone impacts on $\mathrm{CH}_{4}$ emission}

Exposure to the NFA+35/10 $\mathrm{O}_{3}$ treatment resulted in a $27 \%$ reduction in $\mathrm{CH}_{4}$ emission during summer. This finding is consistent with results from our earlier study (Toet et al., 2011) using a different temperate peatland community in response to comparable elevated $\mathrm{O}_{3}$ exposures, suggesting that the effect may be more widespread. However, the two treatments involving $24 \mathrm{~h}$ year-round elevation of $\mathrm{O}_{3}$ concentrations (NFA+10 and NFA+25), resulted in no significant decrease in seasonal $\mathrm{CH}_{4}$ emissions, despite the $24 \mathrm{~h}$ mean $\mathrm{O}_{3}$ concentration 
and AOT40 values (see Supplementary Information Table S2), being higher in NFA+25 than in NFA+35/10; indeed, in the final summer, $\mathrm{CH}_{4}$ emissions tended to increase in NFA+10. This difference was not an artefact of $\mathrm{CH}_{4}$ emissions being measured during the day, when $\mathrm{NFA}+35 / 10$ exposures were higher, as in both ambient $\mathrm{O}_{3}$ and NFA+35/10, $\mathrm{CH}_{4}$ emissions showed relatively weak diurnal variation (data not shown). Part of the reason for the lack of response to $24 \mathrm{~h}$ exposure may be stomatal closure at night-time, and hence reduced stomatal flux into sedge leaves; however, stomata may also have been (partly) open at night as found in several plant species including sedges (Caird et al., 2007, Gebauer et al., 1998). Ozone exposure has also been observed to make stomata sluggish, increasing nocturnal transpiration and $\mathrm{O}_{3}$ uptake (Davison \& Barnes, 2002; Hoshika et al., 2013). Although the air temperature was on average $3.8^{\circ} \mathrm{C}$ higher in the OTCs than at the Scottish field site, the mean summer $\mathrm{CH}_{4}$ emission rates of 2-12 $\mathrm{mg} \mathrm{C} \mathrm{m}^{-2} \mathrm{~h}^{-1}$ were within the range of field flux rates in other sedge-dominated peatlands within the UK (Greenup et al., 2000; Gauci et al., 2002; McNamara et al., 2008; Toet et al., 2011; Levy et al., 2012: 0.1-14 $\mathrm{mg} \mathrm{m}^{-2} \mathrm{~h}^{-1}$ ) and Northern Europe (Granberg et al. 2001, Rinnan et al. 2003, Mörsky et al. 2008: 0.7-16 $\mathrm{mg} \mathrm{m}^{-2} \mathrm{~h}^{-1}$ ).

However, the results from both this and our previous study in open-top chambers (OTCs) (Toet et al. 2011) were not consistent with the findings of the four-year mire open-air fumigation study of Mörsky et al. (2008), who reported no overall long-term responses of $\mathrm{CH}_{4}$ emissions to elevated $\mathrm{O}_{3}$, which were comparable to our NFA+35/10 treatment. The use of OTCs, rather than a field release system, may modify the size of the effect of a given ozone concentration, but these different findings may also be due to a range of other factors, including local climate, soil microbiota, and peat chemistry. Our results are also inconsistent with the summer-long closed-chamber experiment of Williamson et al. (2016), although the non-significant tendency for increased $\mathrm{CH}_{4}$ emissions in the lower background $\mathrm{O}_{3}$ treatment by the end of the experiment, was consistent with their report that relative small increases in 
background $\mathrm{O}_{3}$ exposure may increase $\mathrm{CH}_{4}$ emissions, which suggests a hormetic dose response relationship (Calabrese 2005). Rinnan et al. (2013) suggested that $\mathrm{CH}_{4}$ responses to elevated $\mathrm{O}_{3}$ are rather small in these boreal peatlands, compared to other environmental factors (e.g. temperature, water table and light). However, consistent with our findings at NFA+35/10, decreased $\mathrm{CH}_{4}$ emissions have been reported for three OTC studies on rice paddies in which $\mathrm{O}_{3}$ concentrations were elevated for 7-8h during the day (Bhatia et al., 2011; Zheng et al., 2011; Tang et al., 2015). Tang et al. (2015) derived a dose-response relationship from these three experiments; $\mathrm{CH}_{4}$ emissions declined by $2.3 \%$ for every $1 \mathrm{ppm} . \mathrm{h}$ increase in annual AOT40. This is a stronger effect than the $0.7 \%$ for every $1 \mathrm{ppm} . \mathrm{h}$ we calculated for impacts in the NFA $+35 / 10$ treatment in the experiment reported here.

\subsection{Plant-mediated ozone responses}

Elevated $\mathrm{O}_{3}$ effects on $\mathrm{CH}_{4}$ emissions are probably not caused by direct impacts on soil microbial populations since $\mathrm{O}_{3}$ is very reactive, and $\mathrm{O}_{3}$ and its reaction products have been shown not to penetrate deeper than the top few mm of soils (Toet et al., 2009). Ozone is also unlikely to penetrate through the aerenchyma, as it is expected to react rapidly on contact with moist plant surfaces. We cannot exclude the possibility of reduced transport of $\mathrm{CH}_{4}$ through the aerenchyma of sedge plants due to elevated $\mathrm{O}_{3}$, although Mörsky et al. (2008) reported no significant effect of $\mathrm{O}_{3}$ on the proportion of aerenchymatous tissue in Eriophorum vaginatum leaves, and there was no significant effect of $\mathrm{O}_{3}$ on sedge green leaf density of the sedges in our study; furthermore, sedge leaf density did not correlate positively with $\mathrm{CH}_{4}$ emissions.

We concluded from this that the effects of elevated $\mathrm{O}_{3}$ are likely to be linked to processes occurring below-ground that are mediated indirectly by plants, e.g. through reduced root biomass and turnover, altered root exudation, litter biomass or litter quality. There is 
evidence from rice paddies that $\mathrm{O}_{3}$-induced reductions in $\mathrm{CH}_{4}$ emissions are due to reduced $\mathrm{C}$ allocation below-ground leading to reduced availability of soil organic $\mathrm{C}$ and hence decreased microbial activity. For example, Bhatia et al. (2011) reported reduced $\mathrm{CH}_{4}$ emissions associated with lower root activity (as measured by reduced dehydrogenase activity), and lower DOC concentrations. Similarly, Tang et al. (2015) attributed reduced $\mathrm{CH}_{4}$ emissions to reduced biomass allocation below-ground (root biomass declined by 35\%) which they linked to an associated inhibition of $\mathrm{CH}_{4}$ production potential. Feng et al. (2013) also reported that DOC concentrations were reduced by $20 \%$ in this study.

Sedge root biomass was not significantly affected by elevated $\mathrm{O}_{3}$ during our study ( $\mathrm{S}$. Toet, unpublished data), contrary to expectation, and pore water DOC concentrations were also not significantly affected by $\mathrm{O}_{3}$; indeed the trend was for increased, rather than decreased, DOC concentrations. Effects on root biomass were not reported by Mörsky et al. (2008), although they found increased pore water concentrations of organic acids (including acetate) under elevated $\mathrm{O}_{3}$. Jones et al. (2009) reported that $\mathrm{O}_{3}$ had no significant effect on DOC concentrations in bog microcosms dominated by Sphagnum species, but caused a large reduction in DOC concentrations in microcosms dominated by Festuca and Juncus species; this was attributed to a reduction in root exudates, causing a shift in microbial consumption from root exudates to soil $\mathrm{C}$ pools.

Results from our ${ }^{13} \mathrm{C}$ pulse labelling study clearly demonstrate that elevated $\mathrm{O}_{3}$ did not alter the contribution of recent photosynthate to $\mathrm{CH}_{4}$ emissions, even though $\mathrm{CH}_{4}$ emissions from these labelled cores were reduced by $28 \%$. Recent photosynthate was estimated to contribute only $12 \%$ of $\mathrm{CH}_{4}$ emissions in August-September, a relatively low percentage compared to other peatlands with sedges (>75\%: King et al., 2002; 32\%: unpublished data, S. Toet) and anaerobic rice paddies (22-45\% for the entire growth period, Minoda et al., 1996; Tokida et al., 2011). Impacts on recent photosynthate are therefore not 
the main source for $\mathrm{CH}_{4}$ production in this wet heath, at least not in early August, suggesting that the hydrogenotrophic pathway using less recent $\mathrm{C}$ sources rather than the acetoclastic pathway using more labile organic $\mathrm{C}$ may have been more prevalent in $\mathrm{CH}_{4}$ production in the mesocosms (e.g. Hornibrook et al., 2000). This was not clearly supported by the apparent fractionation factors of 1.055 and 1.057 for pore water observed at $20 \mathrm{~cm}$ and $30 \mathrm{~cm}$ depth, as they are borderline in indicating the dominance of either pathway (Whiticar et al., 1986; Whiticar, 1999; Conrad, 2005; Holmes et al., 2015). These values were, however, probably lowered, indicating more prevalence towards acetoclastic methanogenesis, due to $\mathrm{C}$ isotopic fractionation of $\mathrm{CH}_{4}$ during aerobic, anaerobic or facultative $\mathrm{CH}_{4}$ oxidation when the $\mathrm{CH}_{4}$ passed the peat profile to the moss surface (Semrau et al., 2011; Smemo \& Yavitt, 2011; Whiticar, 1999). Dominance of the hydrogenotrophic pathway has been observed in several sedge-dominated peatlands (Whiticar et al., 1986; Mörsky et al., 2008; Holmes et al., 2015) and may also explain the lack of increase in $\mathrm{CH}_{4}$ emission despite the increase in organic acid concentrations (including acetate) in the peat pore water at elevated $\mathrm{O}_{3}$ in the peatland microcosm study of Mörsky et al. (2008). Transient shifts in pathway dominance are less likely as similar contributions of recent photosynthates to $\mathrm{CH}_{4}$ emission and also no effect of elevated $\mathrm{O}_{3}$ were observed in the previous summer (data not shown), but seasonal shifts cannot be excluded. Overall, and in contrast to our original hypotheses, and findings from rice paddies, there is no evidence that the observed decrease in $\mathrm{CH}_{4}$ emission caused by elevated $\mathrm{O}_{3}$ was due to reduced organic $\mathrm{C}$ substrate availability.

\section{3. $\mathrm{CH}_{4}$ production and oxidation potential}

Methane production potential in the final summer of our study was significantly reduced in the two treatments providing $24 \mathrm{~h}$ fumigation $(\mathrm{NFA}+10$ and NFA+25), but not in NFA+35/10. The greatest reduction in production potential, of $61 \%$, was found in the highest $24 \mathrm{~h}$ mean $\mathrm{O}_{3}$ 
exposure $(\mathrm{NFA}+25)$. Methane production potential was only measured at 20-25 cm, the depth with highest production potential in a pilot study. However, there was still considerable production potential at $10-15 \mathrm{~cm}$, and we cannot rule out the possibility that $\mathrm{O}_{3}$ had different effects at shallower depths.

Aerobic $\mathrm{CH}_{4}$ oxidation potential was reduced, by an average of $63 \%$ in the top, partly green, Sphagnum layer in the NFA+25 and NFA+35/10 treatments. The high aerobic $\mathrm{CH}_{4}$ oxidation potential in the Sphagnum layer is consistent with the findings of Raghoebarsing et al. (2005) and Larmola et al. (2010), who showed $\mathrm{CH}_{4}$ consumption by Sphagnum plants through partly endophytic methanotrophs in hyaline cells and on stem leaves. However, reduced $\mathrm{CH}_{4}$ oxidation rates should result in higher $\mathrm{CH}_{4}$ emission rates, rather than the lower $\mathrm{CH}_{4}$ emission rates that we found in NFA+35/10. There was no significant elevated $\mathrm{O}_{3}$ effect on oxidation potential at $20-25 \mathrm{~cm}$ although, as for the $\mathrm{CH}_{4}$ production potential, elevated $\mathrm{O}_{3}$ may have had different effects at other depths. It is also possible that the higher $\mathrm{O}_{2}$ availability in the potential measurements mean that actual aerobic $\mathrm{CH}_{4}$ oxidation rates, especially below the water table, may have been lower in situ, or that anaerobic $\mathrm{CH}_{4}$ oxidation may have been important (Smemo \& Yavitt, 2011).

Mörsky et al. (2008) measured $\mathrm{CH}_{4}$ production and aerobic consumption potential at a depth of $8-12 \mathrm{~cm}$ at the end of the third summer. There was no significant effect of elevated $\mathrm{O}_{3}$ on either production or oxidation potential, a result that is consistent with the lack of $\mathrm{O}_{3}$ effects on $\mathrm{CH}_{4}$ emissions in their experiment. However, Feng et al. (2013) reported a strong reduction in methanogenic activity by elevated $\mathrm{O}_{3}$ in paddy soils in an experiment in which elevated $\mathrm{O}_{3}$ reduced both soil DOC and acetate concentrations, and Tang et al. (2015) reported a significant decrease in $\mathrm{CH}_{4}$ emissions in elevated $\mathrm{O}_{3}$. Importantly, Feng et al. (2013) were able to link this finding to changes in the diversity and richness of methanogenic archaea, and reductions in the proportion in certain dominant groups such as the acetoclastic 
Methanosaeta. Earlier studies have also suggested that $\mathrm{O}_{3}$ can affect the soil microbial community of rice paddies. Chen et al. (2010) used PFLA and C source utilisation to show that elevated $\mathrm{O}_{3}$ significantly decreased total microbial biomass and changed soil microbial composition at the end of the growing season, while Feng et al. (2011) reported that elevated $\mathrm{O}_{3}$ reduced the abundance and genetic diversity of anoxygenic purple phototrophic bacteria. Furthermore, Mörsky et al. (2008) also reported, using PFLA biomarkers, that elevated $\mathrm{O}_{3}$ reduced total microbial biomass and altered microbial composition in their peatland microcosms. Hence, although we did not find effects of elevated $\mathrm{O}_{3}$ on $\mathrm{CH}_{4}$ production or oxidation potentials that were consistent with the observed long-term effects on $\mathrm{CH}_{4}$ emissions, it remains likely that changes in the methanogenic and/or methanotrophic communities were the key underlying explanation.

\subsection{Ozone impacts on $N$ cycling}

An alternative explanation for changes in the activity or composition of microbial communities involved in $\mathrm{CH}_{4}$ emissions may relate to indirect effects of elevated $\mathrm{O}_{3}$ on soil $\mathrm{N}$ cycling. In particular, elevated $\mathrm{O}_{3}$ significantly reduced pore water $\mathrm{NH}_{4}$ concentrations at $20 \mathrm{~cm}$ throughout the experiment. Similar trends were observed at shallower depths but they were not significant. The soil $\mathrm{NH}_{4}$ response to elevated $\mathrm{O}_{3}$ was apparent from the first summer of the experiment, when $\mathrm{O}_{3}$ effects on $\mathrm{CH}_{4}$ emission were also first observed. By the final year, $\mathrm{NH}_{4}$ concentrations appeared to increase in the NFA+10 treatment, as did $\mathrm{CH}_{4}$ emission. Overall, a strong positive correlation was found, both between and within $\mathrm{O}_{3}$ treatments, between pore water $\mathrm{NH}_{4}$ concentrations at all depths and $\mathrm{CH}_{4}$ emission. Similar positive correlations were found with $\mathrm{pH}$, which was therefore also closely correlated with $\mathrm{NH}_{4}$ concentrations. 
Previous long-term studies of elevated $\mathrm{O}_{3}$ effects on peatland ecosystems (e.g. Mörsky et al., 2008) have not reported effects on $\mathrm{NH}_{4}$ concentrations or on $\mathrm{N}$ cycling, but negative responses of soil $\mathrm{NH}_{4}$ concentrations to elevated $\mathrm{O}_{3}$ have been observed in rice paddies (Bhatia et al., 2011), meadows (Kanerva et al., 2006) and soybean crops (Pereira et al., 2011). A positive link between soil inorganic $\mathrm{N}$ availability and methanogenic activity is plausible, and $\mathrm{CH}_{4}$ emission in paddy soils has been positively correlated to levels of soil mineralisable $\mathrm{N}$ (e.g. Zheng et al., 2006). However, there may be important differences between these heavily fertilised systems and natural wetlands. The lower $\mathrm{NH}_{4}$ availability also might have promoted methanotrophic activity in the mesocosms (Wang \& Ineson 2003, Keller et al., 2006) and hence reduced $\mathrm{CH}_{4}$ emissions, although there was no evidence of enhanced soil aerobic $\mathrm{CH}_{4}$ oxidation potential at $\mathrm{NFA}+35 / 10$ in our study; in fact the opposite effect was observed in the top layer of the mesocosms.

Most studies attributed reduced soil $\mathrm{NH}_{4}$ concentrations or changes in soil $\mathrm{N}$ concentration or microbial biomass $\mathrm{N}$ in response to elevated $\mathrm{O}_{3}$ to reduced below-ground $\mathrm{C}$ inputs, reduced litter quality (Kanerva et al., 2006; Bhatia et al., 2011; Pereira et al., 2011) or higher nitrification and denitrification rates (Li et al., 2010; Pereira et al., 2011). We have no evidence of such changes in $\mathrm{C}$ inputs in elevated $\mathrm{O}_{3}$ in our study. Aerobic and anaerobic soil respiration potentials were not affected by elevated $\mathrm{O}_{3}$ in the final summer of our experiment. Low peat pore water $\mathrm{NO}_{2}+\mathrm{NO}_{3}$ concentrations and negligible $\mathrm{N}_{2} \mathrm{O}$ emissions ( $\mathrm{S}$. Toet, unpublished data) suggest that enhanced nitrification and/or denitrification responses to elevated $\mathrm{O}_{3}$ were also less likely. The mechanism leading to reduced soil $\mathrm{NH}_{4}^{+}$ concentrations in our study is therefore uncertain.

Other possible explanations for decreased $\mathrm{NH}_{4}$ concentrations may include increased plant uptake of N, increased microbial biomass (Kanerva et al., 2006; Bassin et al., 2015) or decreased $\mathrm{N}_{2}$ fixation rate (Pausch et al., 1996; Li et al., 2013). Increased $\mathrm{N}$ concentrations of 
leaves in response to elevated $\mathrm{O}_{3}$ have been observed in trees and grasslands (Wittig et al., 2009; Bassin et al., 2015), but this has rather been attributed to increased retranslocation of $\mathrm{N}$ after early senescence of part of the leaves, reduced plant size (Wittig et al., 2009) and reduced $\mathrm{N}$ resorption from senescing leaves (Uddling et al., 2006). Moreover, leaf $\mathrm{N}$ concentrations of the green sedge leaves in the final summer of our experiment were, lower at $\mathrm{NFA}+35 / 10$ than at ambient $\mathrm{O}_{3}$ (S. Toet, unpublished data), and, together, with no significant $\mathrm{O}_{3}$ effects on sedge green leaf density and root biomass imply that increased plant uptake of $\mathrm{N}$ at elevated $\mathrm{O}_{3}$ is not very likely. Recent findings suggest that methanotrophy and $\mathrm{N}_{2}$ fixation in peatlands may be linked (Ho \& Bodelier, 2015); Larmola et al. (2014) observed that aerobic methanotrophs contributed to up to $40 \%$ of $\mathrm{N}_{2}$ fixation. Lower rates of energydemanding $\mathrm{N}_{2}$ fixation at elevated $\mathrm{O}_{3}$ may therefore have resulted in higher $\mathrm{CH}_{4}$ oxidation rates and consequently lower $\mathrm{CH}_{4}$ emissions, although this was not confirmed by our aerobic $\mathrm{CH}_{4}$ oxidation potential measurements.

Finally, more than one mechanism may explain the observed effects of elevated $\mathrm{O}_{3}$ on $\mathrm{CH}_{4}$ fluxes: mechanisms may be transient or occur simultaneously. It may be significant that reductions in both $\mathrm{CH}_{4}$ emissions and soil $\mathrm{NH}_{4}$ concentrations were observed within a few weeks of initiation of the $\mathrm{O}_{3}$ treatments. Similar large changes in pore water chemistry (in this case DOC) over a few weeks were reported by Jones et al. (2009), and rapid changes in root respiration in response to $\mathrm{O}_{3}$ have been reported (Andersen, 2003). In contrast, the long-term responses to elevated $\mathrm{O}_{3}$ that led to the changes in $\mathrm{CH}_{4}$ production and oxidation potential that were found in the final summer of the experiment may be linked to different (contributions of) mechanisms.

In conclusion, our data provide evidence of reduced $\mathrm{CH}_{4}$ emissions in temperate peatlands exposed to seasonal $8 \mathrm{~h}$ mean $\mathrm{O}_{3}$ concentrations during summer of about $60 \mathrm{ppb}$. A recent analysis of global ecosystem exposure to $\mathrm{O}_{3}$ (Fuhrer et al., under review), using the 
Community Earth System Model which has been applied globally, for example by Tai et al. (2014), identified large areas of northern hemisphere temperate ecosystems which experience spring and summer $12 \mathrm{~h}$ mean $\mathrm{O}_{3}$ exposures above $55 \mathrm{ppb}$. Hence, our results imply that temperate $\mathrm{CH}_{4}$ emissions across the northern hemisphere are already significantly reduced by $\mathrm{O}_{3}$, and this effect may become greater in future in regions (such as Asia) where precursor emissions are predicted to increase. However, our data also suggest that increases in global background annual mean $\mathrm{O}_{3}$ concentrations within the range predicted for 2050 will have little, if any, effect on $\mathrm{CH}_{4}$ emissions from peatland communities. We reject most of our original five hypotheses about the mechanisms underlying $\mathrm{O}_{3}$ effects on $\mathrm{CH}_{4}$ emissions from peatlands, but we have identified a close association between effects on $\mathrm{NH}_{4}$ concentrations and on $\mathrm{CH}_{4}$ emissions across $\mathrm{O}_{3}$ treatments and time, which suggests that they are mechanistically linked, through effects on the methanogenic and/or methanotrophic communities. This also implies that the global increases in $\mathrm{N}$ deposition which may affect plant species composition, and hence ecosystem processes of temperate ecosystems, including peatlands (Bobbink et al., 2010), may also directly increase $\mathrm{CH}_{4}$ emissions.

\section{Acknowledgements}

Funding: This work was supported by NERC (grant number NE/E015700/1) and a 'grant in kind" from the NERC Life Sciences Mass Spectrometry Steering Committee. We thank Leon van den Berg for his help with field site selection, John Lambert for kind permission to sample peat at MacLeod Estate, and Cat Moody, Debbie Coldwell, Magnus Kelly and James 
Stafford for their field assistance; Alan Craig for technical assistance in support of the OTC facility, and Robert Hodgson and Alan Bell for maintaining the water table in the mesocosms.

\section{References}

Andersen, C.P., 2003. Source-sink balance and carbon allocation below ground in plants exposed to ozone. New Phytol. 157, 213-228.

Ainsworth, E.A., Yendrick, C.R., Sitch, S., Collins, W.J., Emberson, L.D., 2012. The effects of tropospheric ozone on net primary productivity and implications for climate change. Ann. Rev. Plant Biol. 63, 637-661.

Alm, J., Saarnio, S., Nykänen, H., Silvola, J., Martikainen, P.J., 1999. Winter $\mathrm{CO}_{2}, \mathrm{CH}_{4}$ and $\mathrm{N}_{2} \mathrm{O}$ fluxes on some natural and drained boreal peatlands. Biogeochemistry 44, 163-186.

Ashmore, M.R., 2005. Assessing the future global impacts of ozone on vegetation. Plant, Cell Environ. 28, 949-964.

Avnery, S., Mauzerall, D.L., Liu, J.F., Horowitz, L.W., 2011. Global crop yield reductions due to surface ozone exposure: 1. Year 2000 crop production losses and economic damage. Atmos. Environ. 45, 2284-2296.

Bassin, S., Kach, D., Valsangiacomom, A., Mayer, J., Oberholzer, H.-R., Volk, M., Fuhrer, J., 2015. Elevated ozone and nitrogen deposition affect nitrogen pools of subalpine grassland. Environ. Pollut. 201, 67-74. 
Bhatia, A., Ghosh, A., Kumar, V., Singh, S.D., Pathak, H., 2011. Effect of elevated tropospheric ozone on methane and nitrous oxide emission from rice soil in north India. Agric. Ecosys. Environ. 144, 21-28.

Bobbink, R., Hicks, K., Galloway, J., Spranger, T., Alkemade, R., Ashmore, M., Bustamante, M., Cinderby, S., Davidson, E., Dentener, F., Emmett, B., Erisman, J.W., Fenn, M., Gilliam, F., Nordin, A., Pardo, L. and de Vries, W., 2010. Global assessment of nitrogen deposition effects on terrestrial plant diversity: a synthesis. Ecol. Applic. 20, 30-59.

Calabrese, E.J., 2005. Paradigm lost, paradigm found: The re-emergence of hormesis as a fundamental dose response model in the toxicological sciences. Environ. Pollut. 138, 378411.

Chen, Z., Wang, X., Yao, F., Zhen, F., Feng, Z., 2010. Elevated ozone changed soil microbial community in a rice paddy. Soil Sci. Soc. Am. J. 74, 829-837.

Conrad, R., 2005. Quantification of methanogenic pathways using stable carbon isotopic signatures: a review and a proposal. Org. Geochem. 36, 739-752.

Davison, A.W., Barnes, J.D., 1998. Effects of ozone on wild plants. New Phytol. 139, 135151.

Davison, A.W., Barnes, J.D., 2002. Air pollutant-abiotic stress interactions, in: Bell J.N.B., Treshow, M. (Eds.), Air Pollution and Plant Life. Wiley \& Sons, London, pp. 359-377.

Dentener, F., Stevenson D., Ellingsen, K. et al., 2006. The global atmospheric environment for the next generation. Environ. Sci. Technol. 40, 3586-3594.

Feng, Y., Lin, X., Yu, Y., Zhang, H., Chu, H., Zhu, J., 2013. Elevated ground-level $\mathrm{O}_{3}$ negatively influences paddy methanogenic archaeal community. Sci. Rep. 3: 3193, doi:10.138/srep03193. 
Feng, Y., Lin, X., Yu, Y., Zhu, J., 2011. Elevated ground-level $\mathrm{O}_{3}$ changes the diversity of anoxygenic purple phototrophic bacteria in a paddy field. Microb. Ecol. 62, 789-799.

Fuhrer, J., Val Martin, M., Mills, G., Heald, C.L., Harmens, H., Hayes, F., Sharps, K.R., Bender, J., Ashmore, M.R., under review. Current and future ozone risks to global terrestrial biodiversity and ecosystem processes. Glob. Change Biol.

Gauci, V., Dise, N., Fowler, D., 2002. Controls on suppression of methane flux from a peat bog subjected to simulated acid rain sulphate deposition. Glob. Biogeochem. Cycl. 16, 1004, doi:10.1029/2000GB001370.

Gebauer, R.L.E., Reynolds, J.F., Thenhunen, J.D., 1998. Diurnal patterns of $\mathrm{CO}_{2}$ and $\mathrm{H}_{2} \mathrm{O}$ exchange of the arctic sedges Eriophorum angustifolium and E. vaginatum (CYPRACEAE). Am. J. Bot. 85, 592-599.

Gonzalez-Fernandez, I., Bass, D., Mutifering, R., Mills, G., Barnes, J.D., 2008. Impacts of ozone pollution on productivity and forage quality of grass/clover swards. Atmos. Environ. $42,8755-8769$.

Granberg, G., Sundh, I., Svensson, B.H., Nilsson, M., 2001. Effects of temperature, and nitrogen and sulphur deposition, on methane emission from a boreal mire. Ecology 82, 19821998.

Greenup, A.L., Bradford, M.A., McNamara, N.P., Ineson, P., Lee, J.A., 2000. The role of Eriophorum vaginatum in $\mathrm{CH}_{4}$ flux from an ombrotrophic peatland. Plant Soil 227, 265-272.

Ho, A., Bodelier, P.L.E., 2015. Diazotrophic methanotrophs in peatlands: the missing link? Plant Soil 389, 419-423.

Holmes, M.E., Chanton, J.P., Tfaily, M.M., Ogram, A., 2015. $\mathrm{CO}_{2}$ and $\mathrm{CH}_{4}$ isotope compositions and production pathways in a tropical peatland. Glob. Biogeochem. Cycl. 29, 118, doi:10.1002/2014GB004951. 
Hornibrook, E.R.C., Longstaffe, F.J., Fyfe, W.S., 2000. Evolution of stable carbon isotope compositions for methane and carbon dioxide in freshwater wetlands and other anaerobic environments. Geochim. Cosmochim. Acta 64, 1013-1027.

Hoshika, Y., Omasa, K., Paoletti, E., 2013. Both ozone exposure and soil water stress are able to induce stomatal sluggishness. Eviron. Exp. Bot. 88, 19-23.

IPCC, 2013. Climate Change 2013: The Physical Science Basis. Contribution of Working Group I to the Fifth Assessment Report of the Intergovernmental Panel on Climate Change, Stocker, T.F., Qin, D., Plattner, G.-K., et al. (Eds.). Cambridge University Press, Cambridge, UK, and New York, USA.

Isaksen, I.S.A., Bernsten, T.K., Dalsoren, S.B. et al., 2014. Atmospheric ozone and methane in a changing climate. Atmosphere 5, 518-535.

Jones, T.G., Freeman, C., Lloyd, A., Mills, G., 2009. Impacts of elevated atmospheric ozone on peatland below-ground DOC characteristics. Ecol. Engin. 25, 971-977.

Kanerva, T., Palojärvi, A., Rämö, K., Ojanperä, K., Esala, M., Manninen, S., 2006. A 3-year exposure to $\mathrm{CO}_{2}$ and $\mathrm{O}_{3}$ induced minor changes in soil $\mathrm{N}$ cycling in a meadow ecosystem. Plant Soil 286, 61-73.

Kanerva, T., Regina, K., Rämö, K., Ojanperä, K., Manninen, S., 2007. Fluxes of $\mathrm{N}_{2} \mathrm{O}$, $\mathrm{CH}_{4}$ and $\mathrm{CO}_{2}$ in a meadow ecosystem exposed to elevated ozone and carbon dioxide for three years. Environ. Pollut. 145, 818-828.

Keller, J.K., Bauers, A.K., Bridgham, S.D., Kellog, L.A., Iversen, C.M., 2006. Nutrient control of microbial carbon cycling along an ombrotrophic-minerotrophic peatland gradient, Journal of Geophys. Res. - Biogeosciences 111, G03006, doi:10.1029/2005JG000152.

King, J.Y., Reeburgh, W.S., Thieler, K.K., Kling, G.W., Loya, W.M., Johnson, L.C., Nadelhoffer, K.J., 2002. Pulse-labelling studies of carbon cycling in Arctic tundra 
ecosystems: The contribution of photosynthates to methane emission. Glob. Biogeochem. Cycl. 16, 1062, doi:10.1029/2001/GB001456.

Kirschke, S., Bousquet, P., Ciais, P. et al., 2013. Three decades of global methane sources and sinks. Nature Geoscience 6, 813-823.

Kou, T.J., Cheng, X.H., Zhu, J.G., Xie, Z.B., 2015. The influence of ozone pollution on $\mathrm{CO}_{2}$, $\mathrm{CH}_{4}$ and $\mathrm{N}_{2} \mathrm{O}$ emissions from a Chinese subtropical rice-wheat rotation system under free-air $\mathrm{O}_{3}$ exposure. Agric. Ecosyst. Environ. 204, 72-81.

Kou, T., Wang, L., Zhu, J., Xie, Z., Wang, Y., 2014. Ozone pollution influences soil carbon and nitrogen sequestration and aggregate composition in paddy soils. Plant Soil 380, 305313.

Larmola, T., Leppänen, S.M., Tuittila, E.-S., Aarva, M., Merilä, P., Fritze, H., Tiirola, M., 2014. Methanotrophy induces nitrogen fixation during peatland development, PNAS 111, 734-739.

Larmola, T., Luitilla, E.-S., Tiirola, M., Yrjälä,K., Tuomivirta, T., Fritze, H., 2010. The role of Sphagnum mosses in the methane cycling of a boreal mire. Ecology 91, 2356-2365.

Levy, P.E., Burden, A., Cooper, M.D.A., et al., 2012. Methane emissions from soils: synthesis and analysis of a large UK data set. Glob. Change Biol. 18, 1657-1669.

Li, X., Deng, Y., Li, Q. et al., 2013. Shifts of functional gene representation in wheat rhizosphere microbial communities under elevated ozone. ISME J. 7, 660-671.

Li, Q., Lin, X., Hu, J., Zhang, J., Yu, Y., Shen, B., Zu, J., 2010. Effects of elevated $\mathrm{O}_{3}$ concentration in surface layer on activity of soil ammonia-oxidizing bacteria and denitrifying bacteria in wheat field. J. Ecol. Rural Environ. 26, 524-528 (In Chinese, English abstract). 
McNamara, N.P., Black, H.I.J., Pierce, T.G., Reay, D.S., Ineson, P. 2008. The influence of afforestation and tree species on soil methane fluxes from shallow organic soils at the UK Gisburn Forest Experiment. Soil Use Manage. 24, 1-7.

Minoda, T., Kimura, M., Wada, E., 1996. Photosynthates as dominant source of $\mathrm{CH}_{4}$ and $\mathrm{CO}_{2}$ in soil water and $\mathrm{CH}_{4}$ emitted to the atmosphere from paddy fields. J. Geophys. Res. 101, 21091-21097.

Mörsky, S.K., Haapala, J.K., Rinnan, R. et al., 2008. Long-term ozone effects on vegetation, microbial community and methane dynamics of boreal peatland microcosms in open-field studies. Glob. Change Biol. 14, 1891-1903.

Mörsky, S.K., Haapala, J.K., Rinnan, R., Saarnio, S., Silvola, J., Martikainen, P.J., Holopainen, T., 2011. Minor effects of long-term exposure on boreal peatland species Eriophorum vaginatum and Sphagnum papillosum. Environ. Exp. Bot. 72, 455-463.

Pausch, R.C., Mulchi, C.L., Lee, E.H., Meisinger, J.J., 1996. Use of ${ }^{13} \mathrm{C}$ and ${ }^{15} \mathrm{~N}$ isotopes to investigate $\mathrm{O}_{3}$ effects on $\mathrm{C}$ and $\mathrm{N}$ metabolism in soybeans. Part II. Nitrogen uptake, fixation and partitioning. Agric. Ecosyst.Environ. 60, 61-69.

Pereira, E.I.P., Chung, H., Scow, K., Sadowskym M.J., van Kessel, C., Six, J., 2011. Soil transformations under elevated atmospheric $\mathrm{CO}_{2}$ and $\mathrm{O}_{3}$ during the soybean growing season. Environ. Pollut. 159, 401-407.

Raghoebarsing, A.A., Smolders, A.J.P., Schmid, M.C., et al., 2005. Methanotrophic symbionts provide carbon for photosynthesis in peat bogs. Nature 436, 1153-1156.

Rinnan, R., Impio, M., Silvola, J., Holopainen, T., Martikainen, P.J., 2003. Carbon dioxide and methane fluxes in boreal peatlands with different vegetation cover - effects of ozone or ultraviolet-B exposure. Oecologia 137, 475-483. 
Rinnan, R., Saarnio, S., Haapala, J.K., Mörsky, S.K., Martikainen, P.J., Silvola, J., Holopainen, T., 2013. Boreal peatland ecosystems under enhanced UV-B radiation and elevated tropospheric ozone concentration. Environ. Exp. Bot. 90, 43-52.

Royal Society, 2008. Ground-level Ozone in the $21^{\text {st }}$ Century: future trends, impacts and policy implications. Science Policy Report 15/08. The Royal Society, London, UK.

Saarnio, S., Alm, J., Martikainen, P.J., Silvola, J., 1998. Effects of raised $\mathrm{CO}_{2}$ on potential $\mathrm{CH}_{4}$ production and oxidation in, and $\mathrm{CH}_{4}$ emission from a boreal mire. J. Ecol. 86, 261-268.

Semrau, J.D., DiSpirito, A.A., Vuilleumier, S., 2011. Facultative methanotrophy: false leads, true results, and suggestions for future research. FEMS Microb. Lett. 323, 1-12, doi: 0.1111/j.1574-6968.2011.02315.x.

Shindell, D., Kuylensierna, J.C.I., Vignati, E., et al., 2012. Simultaneously mitigating nearterm climate change and improving human health and food security. Science 335, 183-189.

Sitch, S., Cox, P.M., Collins, P.W., Huntingford, V., 2007. Indirect radiative forcing of climate through ozone effects on the land-carbon sink. Nature 448, 791-794.

Smemo, K.A., Yavitt, J.B., 2011. Anaerobic oxidation of methane: an underappreciated aspect of methane cycling in peatland ecosystems? Biogeosciences 8, 779-793.

Subke, J.A., Vallack, H.W., Magnusson, T., Keel, S.G., Metcalfe, D.B., Hogberg, P., Ineson, P., 2009. Short-term dynamics of abiotic and biotic soil ${ }^{13} \mathrm{CO}_{2}$ effluxes after in situ ${ }^{13} \mathrm{CO}_{2}$ pulse labelling of a boreal pine forest. New Phytol. 183, 349-357.

Tai, A.P.K., Martin M.V., Heald, C.L., 2014. Threat to future global food security from climatechange and ozone air pollution. Nature Clim. Change 4, 817-821. 
Tang, H., Liu, G., Zhu, J., Kobayashi, K., 2015. Effects of elevated ozone concentration on $\mathrm{CH}_{4}$ and $\mathrm{N}_{2} \mathrm{O}$ emissions from paddy soil under fully open-air field conditions. Glob. Change Biol. 21, 1727-1736.

Toet, S., Ineson, P., Peacock, S., Ashmore, M.R., 2011. Elevated ozone reduces methane emissions from peatland mesocosms. Glob. Change Biol. 17, 288-296.

Toet, S., Subke, J.-A., D’Haese, D., Ashmore, M.A., Emberson, L.D., Crossman, Z., Evershed, R.P., Barnes, J.D., Ineson, P., 2009. A new stable isotope approach identifies the fate of ozone in plant-soil systems. New Phytol. 182, 85-90.

Tokida, T., Adachi, M., Cheng, W., et al., 2011. Methane and soil $\mathrm{CO}_{2}$ production from current-season photosynthates in a rice paddy exposed to elevated $\mathrm{CO}_{2}$ concentration and soil temperature. Glob. Change Biol. 17, 3327-3337.

Uddling, J., Karlsson, P.E., Glorvigen, A., Selldén, G., 2006. Ozone impairs autumnal resorption of nitrogen from birch (Betula pendula) leaves, causing an increase in whole-tree nitrogen loss through litter fall. Tree Physiol. 26, 113-120.

Wang, Z.P., Ineson, P., 2003. Methane oxidation in a temperate coniferous forest soil: effects of inorganic N. Soil Biol. Biochem. 35, 427-433.

West, J.J., Fiore, A.M., 2005. Management of tropospheric ozone by reducing methane emissions. Environ. Sci. Technol. 38, 4685-4691.

Whiticar, M.J., 1999. Carbon and hydrogen isotope systematic of bacterial formation and oxidation of methane. Chem. Geol. 161, 291-314.

Whiticar, M.J., Faber, E., Schoell, M., 1986. Biogenic methane formation in marine and fresh-water environments: $\mathrm{CO}_{2}$ reduction vs. acetate fermentation - Isotope evidence. Geochim. Cosmochim. Acta 50, 693-709. 
Wild, O., Fiore, A.M., Shindell, D.T., et al., 2012. Modelling future changes in surface ozone: a parameterized approach. Atmospheric Chem. Phys. 12, 2037-2054.

Willamson, J.L., Mills, G., Hayes, F., Jones, T., 2016. How do increasing background concentrations of tropospheric ozone affect peatland plant growth and carbon gas exchange? Atmos. Environ. 127, 133-138.

Wittig, V.E., Ainsworth, E.A., Naidu, S.L., Karnosky, D.F., Long, S.P., 2009. Quantifying the impact of current and future tropospheric ozone on tree biomass, growth, physiology and biochemistry: a quantitative meta-analysis. Glob. Change Biol. 15, 396-424.

Zar, J.H., 1984. Biostatistical Analysis. Prentice Hall, Englewood Cliffs, New Jersey, USA.

Zheng, X., Zhou, Z., Wang, Y., et al., 2006. Nitrogen-regulated effects of free-air enrichment on methane emissions from paddy rice fields. Glob. Change Biol. 12, 1717-1732.

Zheng, F., Wang, X., Lu, F., et al., 2011. Effects of elevated ozone concentration on methane emission from a rice paddy in Yangtze River Delta, China. Glob. Change Biol. 17, 898-910. 